\title{
Comparison of cross-platform technologies for EGFR T790M testing in patients with non-small cell lung cancer
}

\author{
Xuefei $\mathrm{Li}^{1}$ and Caicun Zhou ${ }^{2}$ \\ ${ }^{1}$ Department of Lung Cancer and Immunology, Shanghai Pulmonary Hospital, Tongji University School of Medicine, Pulmonary \\ Cancer institute, Tongji University School of Medicine, Shanghai, P. R. China \\ 2 Department of Medical Oncology, Shanghai Pulmonary Hospital, Tongji University, Tongji University Medical School Cancer \\ Institute, Shanghai, P. R. China
}

Correspondence to: Caicun Zhou, email: caicunzhoudr@163.com

Keywords: EGFR mutations, TKI resistance, circulating tumor DNA, NSCLC, companion diagnostics

Received: April 28, $2017 \quad$ Accepted: June 19, $2017 \quad$ Published: July 05, 2017

Copyright: Li et al. This is an open-access article distributed under the terms of the Creative Commons Attribution License 3.0 (CC BY 3.0 ), which permits unrestricted use, distribution, and reproduction in any medium, provided the original author and source are credited.

\section{ABSTRACT}

Somatic mutations in the gene encoding epidermal growth factor receptor (EGFR) play an important role in determining targeted treatment modalities in nonsmall cell lung cancer (NSCLC). The EGFR T790M mutation emerges in approximately $50 \%$ of cases who acquire resistance to tyrosine kinase inhibitors. Detecting EGFR T790M mutation in tumor tissue is challenging due to heterogeneity of the tumor, low abundance of the mutation and difficulty for re-biopsy in patients with advanced disease. Alternatively, circulating tumor DNA (ctDNA) has been proposed as a noninvasive method for mutational analysis. The presence of EGFR mutations in ctDNA predicts response to the EGFR TKIs in the first-line setting. Molecular testing is now considered a standard care for NSCLC. The advent of standard commercially available kits and targeted mutational analysis has revolutionized the accuracy of mutation detection platforms for detection of EGFR mutations. Our review provides an overview of various commonly used platforms for detecting EGFR T790M mutation in tumor tissue and plasma.

\section{INTRODUCTION}

Lung cancer is a major cause of cancer deaths with approximately $80 \%$ of cases accounting to nonsmall cell lung cancer (NSCLC) [1]. In NSCLC target therapy, epidermal growth factor receptor (EGFR) is a promising candidate [2]. The frequency of EGFR mutation among Asian NSCLC populations is approximately $30 \%$ compared with approximately $10 \%$ in Caucasians [3-5]. EGFR TKIs like gefitinib, erlotinib, and afatinib are used for EGFR targeted therapy in NSCLC [6,7]. The mode of action of tyrosine kinase inhibitors is to inhibit the kinase activation and signal transduction downstream by binding to the ATP binding site of the kinase domain of EGFR [7]. This targeted therapy has shown 56 to $74 \%$ of response rate with median of 10-14 months of progression free survival (PFS) $[8,9]$.

Most common mutations of EGFR gene include inframe deletions of exon 19 and heterozygous mutations of exon 21 [7]. The correlation between EGFR mutations and EGFR TKI sensitivity has shown prognostic potential as demonstrated from various clinical trials $[10,11]$. Although, patients respond well, initially to EGFR TKIs, majority of them acquire resistance due to the emergence of secondary T790M resistance mutation which abrogates the TKIs inhibitory action [12-15]. This can be overcome by use of second-generation EGFR inhibitors (afatinib and dacomitinib), however, these inhibitors showed low response rate $(<10 \%)$ and low PFS ( $<4$ months) [1618]. They are also associated with skin and gastrointestinal toxic effects $[19,20]$. A third-generation EGFR TKI that is potent to T790M resistance mutation is AZD9291. This is shown to be effective with a response rate of $61 \%$ and limited skin and gastrointestinal adverse events in patients who developed T790M mediated resistance to EGFR TKIs. AZD9291 also targets EGFR sensitizing mutations (exon 19 deletion and L858R) [21, 22].

Monitoring post-TKI progression events in tumor tissue has drawn much importance as it assists in designing therapeutic strategies to overcome resistant 
mechanisms. In order to study these mechanisms of resistance re-biopsies are recommended, however in clinical practice this becomes challenging due to invasive procedure and heterogeneity of the tumor tissue [23, 24]. A non-invasive alternative to tissue is circulating tumor DNA (ctDNA) that has emerged recently and is reported as specific and sensitive biomarker for EGFR mutation detection. Mutations detected in tumor tissue showed high concordance with those observed in plasma ctDNA [2527].

Several clinical platforms are available to detect EGFR mutations including amplification refractory mutation system (ARMS), cobas TaqMan-based PCR, digital polymerase chain reaction (PCR) including droplet digital PCR (ddPCR) and BEAMing (beads, emulsions, amplification, and magnetics) digital PCR, mutantenriched PCR, high-resolution melting (HRM) analysis, denaturing high performance liquid chromatography (DHPLC) and next generation sequencing (NGS). These techniques vary in their sensitivity and their specificity in their rate of detection in plasma and tumor tissue.

Real-time monitoring of EGFR mutations is essential for determining appropriate treatment strategies; therefore, less invasive procedures combined with highly sensitivity, specificity, cost-effective diagnostic platform remains an unmet need. Hence, we review the existing EGFR T790M mutation testing technologies and their sensitivity and specificity in detecting these mutations in plasma, tissue and bodily fluid samples.

\section{COMPANION DIAGNOSTIC PLATFORMS FOR EGFR T790M MUTATION DETECTION}

Currently several PCR based diagnostic platforms are available for EGFR mutation detection including cobas, ARMS, BEAMing, droplet PCR, HRM, DHPLC, mass spectrometry genotyping, electric field-induced release and measurement (EFIRM) and NGS. Here we review the varying sensitivity and specificity of most widely used platforms and their use in plasma and tumor tissue. Table 1 represents the salient features of the companion diagnostic platforms used for EGFR mutation detection.

\section{Cobas (Roche)}

This is a real-time PCR based technique that identifies 42 locus mutations of EGFR including T790M. The procedure has two steps, step one is extraction of DNA from tissue or plasma and the second step is amplification of DNA using specific primers and detection using probes with fluorescent dyes. It is designed to run both tissue and plasma samples on the same plate thus giving clinicians the ease of comparison for planning therapeutic strategies.
Plasma samples are processed using cobas cfDNA sample preparation kit after separating plasma from the whole blood whereas, for tissue samples cobas DNA sample preparation kit is used for extraction of DNA. After sample preparation, amplification and detection is done by running the samples together on the same plate in PCR , thus providing a head to head comparison of tissue with plasma [28]. Figure 1 depicts the workflow of cobas in tissue and plasma.

\section{ARMS}

Allele specific polymerase chain reaction is designed using sequence specific PCR primers and is useful in detecting small deletions or single base mutations [30]. Specific mutated sequences are amplified selectively as Taq DNA polymerase distinguishes a match and a mismatch at 3' end of the primer, thus amplifying only the target allele DNA. When there is full match good amplification occurs and in mismatch low background amplification is observed. PCR primers covalently bond to a probe; fluorophore of the probe interacts with a quencher (incorporated in the probe) reducing fluorescence. During PCR the probe binds to the amplicon separating the fluorophore and the quencher thus increasing fluorescence in the PCR tube [31].

ARMS (Qiagen): EGFR RGQ PCR Kit version 2 is a diagnostic kit that detects mutations using real-time PCR on the Rotor-Gene Q 5plex HRM instrument. The procedure has two steps, first step consists of the control assay for assessing the total sample DNA and second step has both control and mutation assay to assess mutated DNA [32, 33]. Figure 2 depicts the principle of ARMS.

ARMS (AmoyDx): AmoyDx ${ }^{\circledR}$ EGFR Mutation Detection Test (CE-IVD) is a diagnostic kit that detects EGFR mutations in exon 18, 19, 20 and 21. This technology works using two step PCR amplification procedures combined with novel fluorescent probe design and can be used for fresh or frozen tissue samples, blood serum or plasma [34].

\section{Digital PCR}

Digital PCR clonally amplifies and quantifies nucleic acids. It can amplify and generate amplicons derived from one template using very less sample. Different alleles can be distinguished using fluorophores or sequencing. It is superior to conventional PCR as it transforms the exponential analog signals and gives a linear digital signal output suitable for statistical analysis [35].

Sysmex Inostics BEAMing Digital PCR technology is a highly sensitive platform that combines emulsion PCR with magnetic beads and flow cytometry. The workflow involves isolation of DNA and amplification of DNA by 
COBAS WORKFLOW

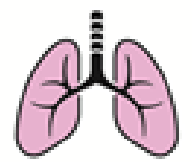

Tissue

Workflow

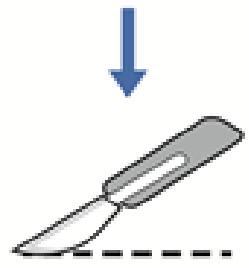

Tissue Biopsy

Sample

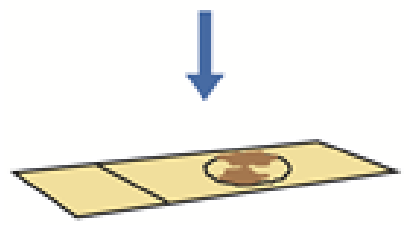

Macro Dissect

Tumor Content
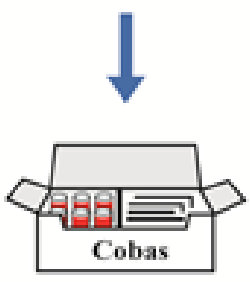

Cobas DNA

Sample Prep

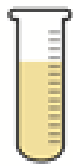

Plasma

Workflow

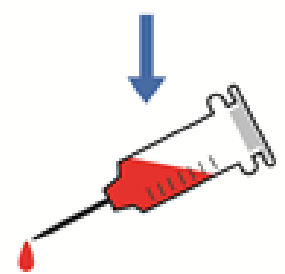

Draw Blood

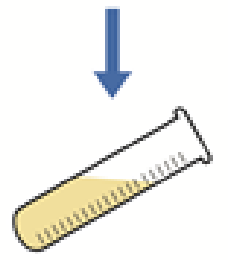

Separate Plasma Form Blood

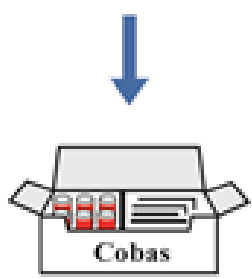

Cobas efDNA

Sample Prep
ARMS WORKFLOW

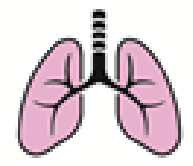

Tissue

Workflow

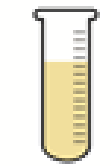

Plasma

Workflow

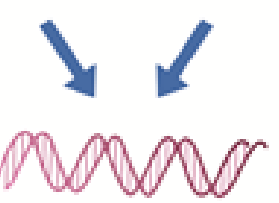

DNA extraction

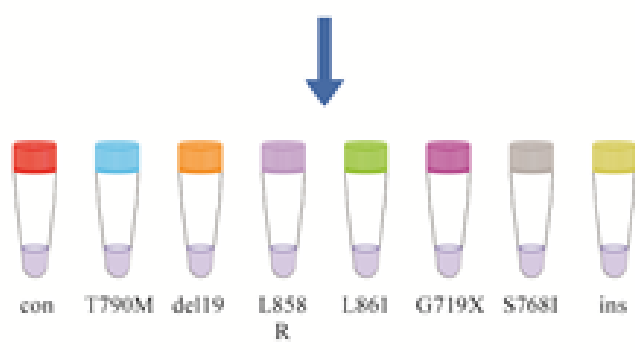

DNA Sample added to 8 different reaction tubes

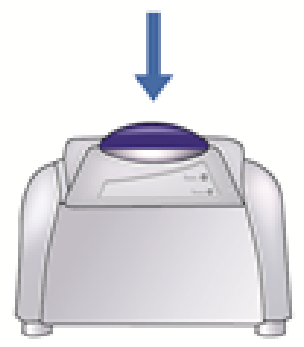

Real-time PCR is run

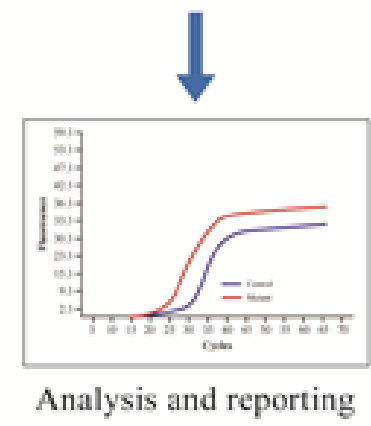

Figure 1: Workflow of cobas (Roche) [28] and ARMS (Qiagen) [29]. The workflow includes sample collection, isolation of DNA from the sample using specific DNA sample preparation kit, running the sample DNA in real-time PCR and results are used for clinical interpretation and targeted therapy 
Table 1: Companion diagnostic platforms for EGFR mutation detection

\begin{tabular}{|c|c|c|c|c|c|c|c|c|}
\hline \multirow{2}{*}{$\begin{array}{l}\text { Platform } \\
\begin{array}{l}\text { Commercially } \\
\text { available kit/brand }\end{array}\end{array}$} & \multirow{2}{*}{\begin{tabular}{|l} 
Cobas \\
Roche [28]
\end{tabular}} & \multicolumn{2}{|l|}{ ARMS } & \multicolumn{3}{|l|}{ Digital PCR } & \multicolumn{2}{|l|}{ NGS } \\
\hline & & Qiagen $[32,33]$ & Amoydx [34] & Bio-rad ddPCR [37] & $\begin{array}{lr}\text { Sysmex } & \text { Inostics } \\
\text { BEAMing } & \text { Digital } \\
\text { PCR [36] } & \end{array}$ & $\begin{array}{l}\text { Thermo }^{\mathrm{TM}} \\
\text { QuantStudio } \\
\text { 3D Digital PCR } \\
\text { System [38] }\end{array}$ & Illumina Miseq [39] & $\begin{array}{l}\text { Thermo Fisher } \\
\text { Ion Torrent [41] }\end{array}$ \\
\hline Technique & $\begin{array}{lr}\text { Real-time } & \text { PCR } \\
\text { using } & \text { TaqMan } \\
\text { Probes } & \\
\end{array}$ & $\begin{array}{lr}\text { ARMS } & \text { Scorpion } \\
\text { primers with } & \text { PCR } \\
\text { technology }\end{array}$ & $\begin{array}{l}\text { ARMS PCR based } \\
\text { technology with } \\
\text { florescent probe }\end{array}$ & $\begin{array}{l}\text { Water-emulsion } \\
\text { droplet technology }\end{array}$ & $\begin{array}{l}\text { Emulsion PCR with } \\
\text { magnetic beads and } \\
\text { flow cytometry }\end{array}$ & $\begin{array}{l}\text { Chip } \\
\text { technology }\end{array}$ & $\begin{array}{l}\text { Sequencing by } \\
\text { synthesis technology }\end{array}$ & $\begin{array}{l}\text { Semiconductor } \\
\text { chip based } \\
\text { technology }\end{array}$ \\
\hline $\begin{array}{l}\text { EGFR Mutations } \\
\text { coverage }\end{array}$ & $\begin{array}{l}42 \text { mutations in } \\
\text { exon } 18,19,20 \text { and } \\
21 \text { of EGFR gene }\end{array}$ & $\begin{array}{l}29 \text { mutations in exon } \\
18,19,20 \text { and } 21 \text { of } \\
\text { EGFR gene }\end{array}$ & $\begin{array}{l}29 \text { mutations in exon } \\
18,19,20 \text { and } 21 \text { of } \\
\text { EGFR gene }\end{array}$ & \multicolumn{5}{|c|}{ Broad mutation coverage requires specific primer/probe design } \\
\hline Turnaround time & 1 day & $<1$ day & $<1$ day & $<1$ day & 7 10 days & $<1$ day & $8 \sim 10$ days & $8 \sim 10$ days \\
\hline Characteristics & $\begin{array}{l}\text { Qualitative and } \\
\text { semi-quantitative }\end{array}$ & Qualitative & Qualitative & Quantitative & Quantitative & Quantitative & Quantitative & Quantitative \\
\hline Effort & Less laborious & Less laborious & Less laborious & Less laborious & Intermediate & Less laborious & High & High \\
\hline Analysis of results & $\begin{array}{lr}\text { Simple, } & \text { Automated } \\
\text { detection } & \text { through } \\
\text { cobas r z r } & 480 \\
\text { analyzer. } & \\
\end{array}$ & Simple & Simple & $\begin{array}{l}\text { Intermediate, } \\
\text { Quantasoft software } \\
\text { measures the positive } \\
\text { and negative droplets } \\
\text { and gives output in } \\
\text { copies } / \mu 1 \text { of the target } \\
\text { DNA. }\end{array}$ & Intermediate & Intermediate & Complicate & $\begin{array}{l}\text { Complicate, } \\
\text { Automated } \\
\text { analysis } \\
\text { through Ion } \\
\text { Reporter }\end{array}$ \\
\hline Sensitivity & $\begin{array}{l}2 \sim 3 \% \text { for FFPET, } \\
100 \text { copies } / \mathrm{ml} \text { for } \\
\text { plasma (T790M) }\end{array}$ & $1 \%$ & $\begin{array}{l}1 \% \text { for FFPET, } \\
0.2 \% \text { for plasma } \\
\text { SuperARMS) }\end{array}$ & $0.2 \%$ & $0.01 \%$ & $0.1 \%$ & $0.1 \% \sim 0.5 \%$ & $0.1 \% \sim 0.5 \%$ \\
\hline Advantages & $\begin{array}{l}\text { Tissue and Plasma } \\
\text { samples can be run } \\
\text { on the same plate. } \\
\text { FDA approved } \\
\text { method for } \\
\text { mutational analysis. }\end{array}$ & $\begin{array}{l}\text { Low Complexity. FDA } \\
\text { approved method for } \\
\text { mutational analysis. }\end{array}$ & $\begin{array}{lr}\text { Low } & \text { Complexity } \\
\text { CFDA r approved } \\
\text { method rod } \\
\text { mutational analysis. }\end{array}$ & Absolute quantification & n, high sensitivity and s & pecificity & $\begin{array}{l}\text { 1. High throughput; } \\
2 . \text { Can read the } \\
\text { repetitive sequence }\end{array}$ & $\begin{array}{l}\text { 1. Input as less } \\
\text { as 1ng gDNA. } \\
\text { 2.. Low cost; }\end{array}$ \\
\hline Disadvantages & $\begin{array}{l}\text { Does not give absolu } \\
\text { Detects only known } 1\end{array}$ & $\begin{array}{l}\text { te quantification of the mut } \\
\text { nutations. }\end{array}$ & tation. & Detects only known ta & rgeted mutations & & $\begin{array}{l}\text { 1.Longer turnaround } \\
\text { time } \\
\text { 2. High cost } \\
\text { (fluorescence); } \\
\text { 3. Complicate library } \\
\text { preparation. }\end{array}$ & $\begin{array}{l}\text { 1.Longer } \\
\text { turnaround time } \\
2 . \quad \text { Low } \\
\text { throughput; } \\
\text { 3. Complicate } \\
\text { library } \\
\text { preparation. }\end{array}$ \\
\hline
\end{tabular}

PCR. The process involves transformation of a population of DNA molecules into a population of beads coated with primers. This is followed by emulsion PCR and the DNA is hybridised with fluorescent probes. Flow cytometry is performed to read the results [36]. Figure 3 represents the workflow of BEAMing digital PCR.

Droplet Digital PCR Bio-rad technology is based on the water-emulsion droplet technology. DNA sample containing the target DNA is fractionated into 20,000 droplets. End-point PCR amplifies each droplet containing target DNA. Quantification of target DNA is done by counting the positive droplets. This method provides the absolute and precise count of target DNA without the standard curves and has higher sensitivity than real-time PCR [37].

QuantStudio 3D Digital PCR uses a sealed chip technology. It is affordable and has $50 \%$ less price compared to other platforms. The workflow involves diluting the control DNA, digital PCR reaction is run after mixing control DNA, master mix and reference assays. PCR reaction is loaded onto a QuantStudio ${ }^{\circledR}$ 3D Digital PCR 20K chip, lid is applied and loaded with immersion fluid and sealed. The chip is thermal cycled and the results are read and analyzed using QuantStudio ${ }^{\mathrm{TM}}$ 3D Digital PCR Instrument [38].

\section{NGS}

Next-generation sequencing has revolutionized biological research in genome analysis. Illumina MiSeq System is used for targeted genome sequencing and MiSeqDx System is used in molecular diagnostics [39]. Miseq performs sequencing by synthesis technology, a reversible terminator-based method that detects single bases while incorporation into the DNA strands, producing exceptional data quality. This base by base sequencing eliminates errors and produces high quality results. It has simple work flow and has genomic analysis platforms for data analysis and sharing [40]. Thermofisher Ion Torrent NGS technology is powered by semiconductor chips and is simple, scalable and cost-effective method used for targeted sequencing. Ion AmpliSeq technology can amplify thousands of targets using 1ng of genomic DNA or RNA. It can be used for formalin fixed paraffin embedded (FFPE) samples or ctDNA. Sequencing workflow takes less than 2 days. Ion Torrent Oncomine cfDNA Assays can detect mutations at level of $0.1 \%$ in genes. Oncomine Lung cfDNA Assay can detect several hotspots in EGFR genes including T790M [41-43].

\section{SAMPLES FOR EGFR T790M DETECTION}

Tumor biopsy is traditionally used for obtaining 
Scorpion ARMS primers match only mutant DNA thus facilitating extension by Taq DNA polymerase

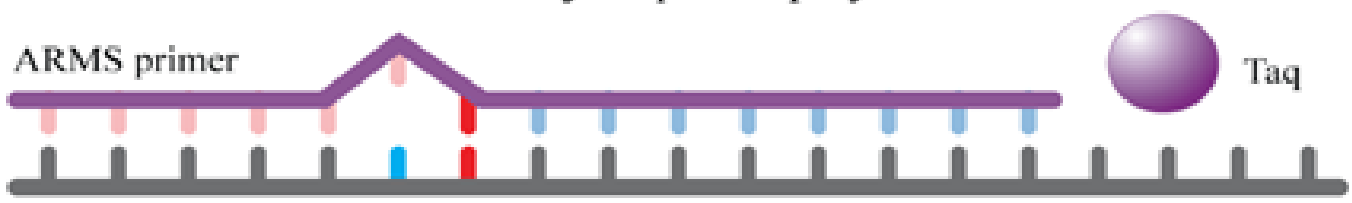

Scorpion mutant primers do not match wild type DNA and there is no extension by Taq polymerase

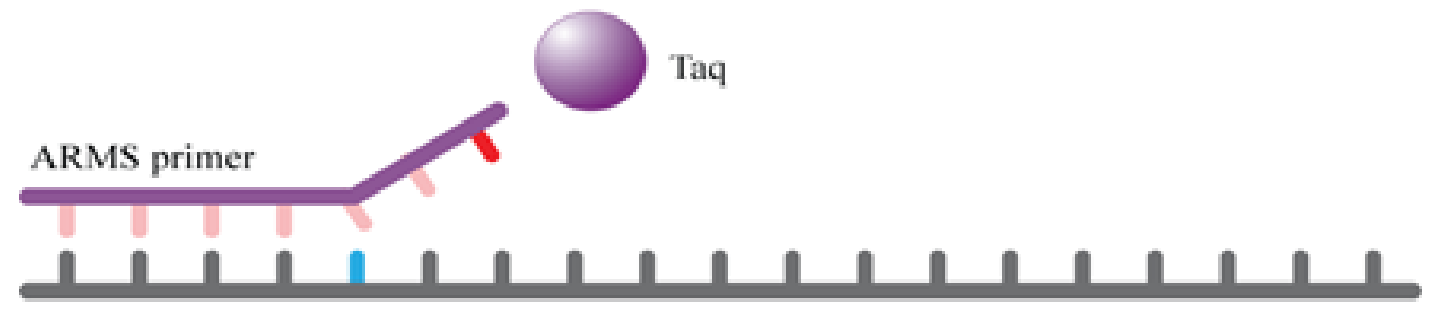

Step 1

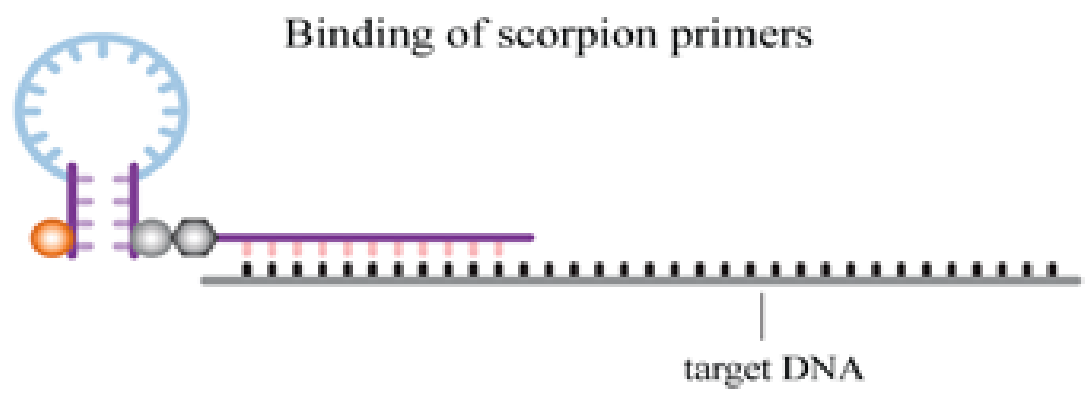

Step 2

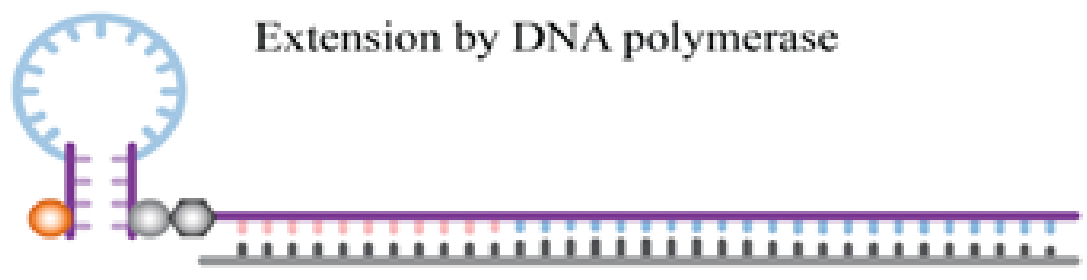

Step 3

Denaturation of scorpion primer

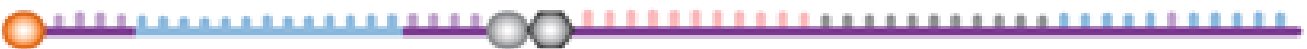

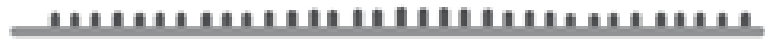

Step 4

Unextended scorpions are quenched and the fluorophore of probe bound to the amplicon emits light
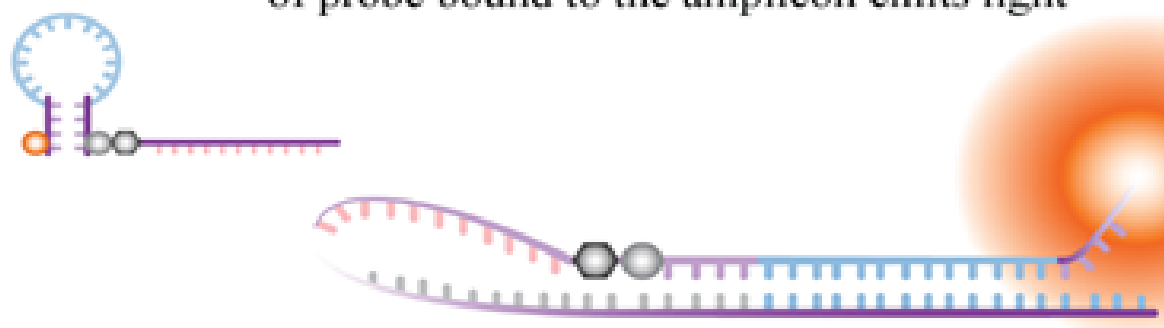

Figure 2: Principle of ARMS (Qiagen) [29]. 
Table 2: Concordance of EGFR T790M mutation detection in tumor and plasma

\begin{tabular}{|c|c|c|c|c|c|c|c|}
\hline \multirow[b]{2}{*}{ S.No } & \multicolumn{2}{|l|}{ Method } & \multirow[b]{2}{*}{ Sample } & \multicolumn{3}{|l|}{ Parameters } & \multirow[t]{2}{*}{ Study group } \\
\hline & Plasma detection & Tissue detection & & Sensitivity & Specificity & \begin{tabular}{|l|} 
Concordance \\
with tissue
\end{tabular} & \\
\hline \multirow{4}{*}{1} & Cobas (Roche) & \multirow{4}{*}{ Cobas (Roche) } & \multirow{4}{*}{ Plasma $N=38$} & $41 \%$ & $100 \%$ & $57 \%$ & \multirow{4}{*}{$\begin{array}{l}\text { Thress et al. } \\
{[70]}\end{array}$} \\
\hline & ddPCR (Bio-rad) & & & $71 \%$ & $83 \%$ & $74 \%$ & \\
\hline & BEAMing & & & $71 \%$ & $67 \%$ & $70 \%$ & \\
\hline & ARMS Qiagen & & & $29 \%$ & $100 \%$ & $48 \%$ & \\
\hline \multirow{2}{*}{2} & Cobas (Roche) & \multirow{2}{*}{ Cobas (Roche) } & \multirow{2}{*}{$\begin{array}{l}\text { Plasma } \\
153\end{array}$} & $64 \%$ & $98 \%$ & $86 \%$ & \multirow{2}{*}{$\begin{array}{l}\text { Karlovich C } \\
\text { et al. [98] }\end{array}$} \\
\hline & BEAMing & & & $73 \%$ & $50 \%$ & $67 \%$ & \\
\hline 3 & BEAMing (Sysmex) & Cobas (Roche) & $\begin{array}{l}\text { Plasma } \quad N= \\
216\end{array}$ & $70.3 \%$ & $69.0 \%$ & NR & $\begin{array}{l}\text { Oxnard GR et } \\
\text { al. [115] }\end{array}$ \\
\hline 4 & ddPCR (Bio-rad) & ARMS (AmoyDx) & Plasma $N=117$ & $81.25 \%$ & $100 \%$ & $81.25 \%$ & $\begin{array}{l}\text { Zheng et al. } \\
\text { [91] }\end{array}$ \\
\hline 5 & ddPCR (Bio-rad) & ddPCR (Biorad) & Plasma $N=18$ & $81.8 \%$ & $85.7 \%$ & $83.3 \%$ & \begin{tabular}{|l}
$\begin{array}{l}\text { Ishii } \mathrm{H} \text { et al. } \\
{[90]}\end{array}$ \\
\end{tabular} \\
\hline 6 & ddPCR (Bio-Rad) & ddPCR (Biorad) & Plasma $N=41$ & $64.5 \%$ & $70.0 \%$ & $65.9 \%$ & \begin{tabular}{|l|} 
Takahama \\
et al. $[116]$
\end{tabular} \\
\hline 7 & \begin{tabular}{|l|}
$\begin{array}{l}\text { Picoliter-ddPCR } \\
\text { (RainDance) }\end{array}$ \\
\end{tabular} & ARMS (Qiagen) & Plasma $N=10$ & $71 \%$ & NR & $80 \%$ & \begin{tabular}{|lll}
$\begin{array}{l}\text { Seki } \\
{[117]}\end{array}$ & et al. \\
\end{tabular} \\
\hline 8 & \begin{tabular}{|l|l|} 
NGS & (Illumina, \\
MiSeq) & \\
\end{tabular} & $\begin{array}{l}\text { Cobas (Roche) and } \\
\text { ARMS (Qiagen) } \\
\end{array}$ & Plasma $N=60$ & $93 \%$ & $94 \%$ & NR & $\begin{array}{l}\text { Reckamp KL } \\
\text { et al. [58] } \\
\end{array}$ \\
\hline 9 & \begin{tabular}{ll|} 
PANAMutyper \\
EGFR kit
\end{tabular} & Ion Torrent NGS & Plasma $N=39$ & $58 \%$ & $68 \%$ & $63 \%$ & \begin{tabular}{|l} 
Han J Y et al. \\
{$[118]$}
\end{tabular} \\
\hline 10 & cSMART & ARMS (AmoyDx) & Plasma $N=61$ & $100 \%$ & NR & $98.4 \%$ & $\begin{array}{l}\text { Chai X et al. } \\
\text { [119] }\end{array}$ \\
\hline 11 & NGS (MiSeq) & $\begin{array}{l}\text { PCR/FISH/NGS } \\
\text { (MiSeq) }\end{array}$ & Plasma $N=15$ & $81.8 \%$ & $100 \%$ & $86 \%$ & \begin{tabular}{|l} 
Paweletz et \\
al. [95]
\end{tabular} \\
\hline
\end{tabular}

information on diagnosis, prognosis, recurrence, drug response and drug resistance. With the advent of targeted therapy, it is now important to continuously monitor the molecular alterations emerging in the tissue which demands a repeat biopsy. Obtaining serial repeat biopsies for real-time monitoring of the disease becomes challenging due to the invasiveness, impractical accessibility, and heterogeneity of tumor tissue [23, 24].

Alternatively, plasma derived ctDNA is promising due to its minimal invasive extraction that could facilitate the monitoring of EGFR mutations [1, 44, 45]. Several studies have indicated that ctDNA is likely to derive from tumor lesions and metastatic sites, possibly representing the patients tumor genome [46, 47]. Plasma ctDNA is promising for mutation detection due to the ease of accessibility, convenience and practicality [27]. It has potential in monitoring the real time disease burden and progression by characterizing intra-tumor and inter-tumor heterogeneity $[48,49]$.

Studies on use of other bodily fluids in mutation detection in lung cancer are limited. Saliva, urine and pleural effusions are some of the clinically available bio-samples that are potentially used in EGFR mutation testing. A core technology called EFIRM has been used for EGFR mutations detection using saliva. Good correlation was observed in EGFR mutation detection between EFIRM and cobas [50]. Several studies have shown use of malignant pleural effusions as an alternative for tissue and blood using PCR for EGFR mutation detection and monitoring [51-53]. Urinary ctDNA has emerged as completely non-invasive sample for assessing disease progression and treatment response in $\mathrm{T} 790 \mathrm{M}$ resistant mutation patients. Most studies have used PCR based technology alone or in combination with NGS [54-57]. A study on kinetics of monitoring T790M mutation in urinary samples revealed $68 \%$ of patients with $\mathrm{T} 790 \mathrm{M}$ mutation post-TKI treatment using PCR coupled with MiSeq. Among these positive patients 10 had similar results with tissue biopsy, three patients who were negative in tissue were detected to be positive in plasma and urine [55]. Another study reported $72 \%$ concordance between urine and tissue results for detecting T790M mutation. Plasma and urine detected additional T790M positive cases that were missed by tissue biopsy [58].

\section{COMPARISON OF DIAGNOSTIC PLATFORMSINEGFRT790MDETECTION IN PLASMA AND TISSUE}

Molecular testing for EGFR gene alterations is 


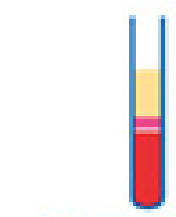

Plasma s

\section{DNA Isolation}

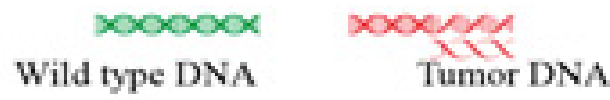

PCR amplification of target region

ater-in-oil emulsion

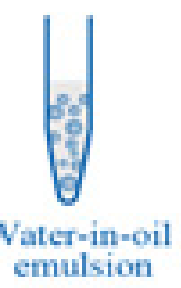

post-cycling
dNTPs

Polymerase

Primer

Oil-Emulsifier Mixture

\section{Pre-Amplification}

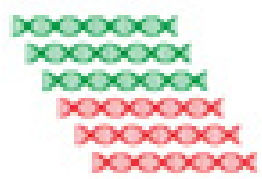

Amplified DNA

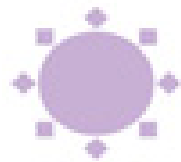

Magnetic beads coated with primer

\section{Emulsion PCR}
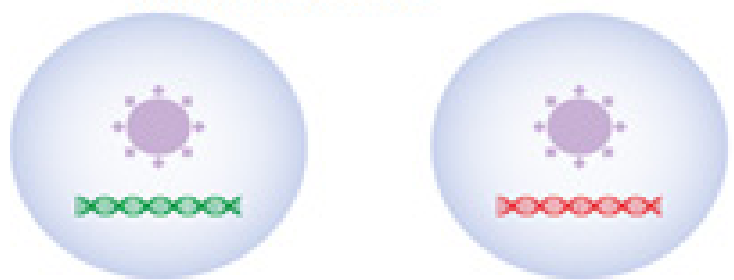

pre-cyeling
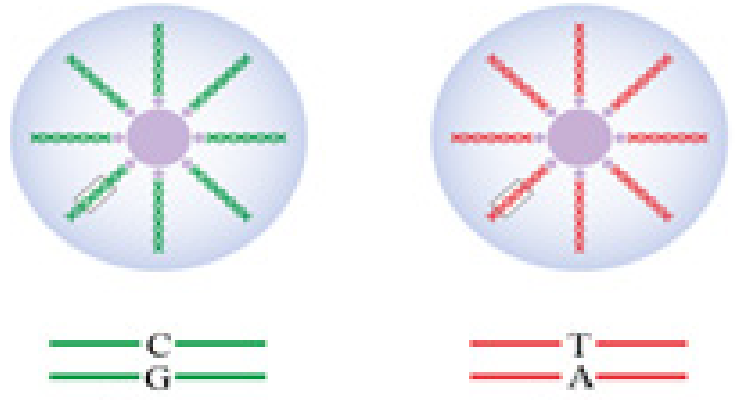

Mutant

\section{Hybridization}
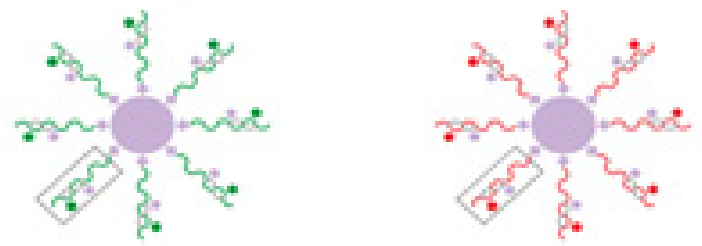

DNA labelled with fluoreseent probes

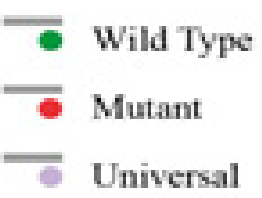

Probes
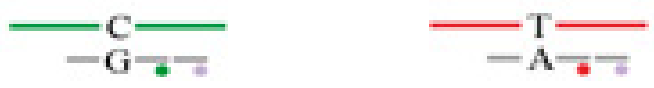

\section{Flow Cytometry}

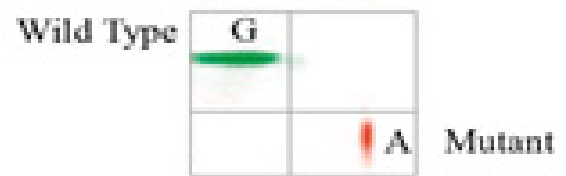

Figure 3: Work flow of Digital PCR (BEAMing) [36]. Droplets are generated using droplet generator and are read using droplet reader. However, QuantStudio digital PCR has much simpler workflow which makes use of chip based technology, the sample is loaded and PCR amplified and the results are read and analyzed using system based software. 
Table 3: Comparison of EGFR T790M detection platforms in plasma

\begin{tabular}{|c|c|c|c|c|c|}
\hline \multirow{2}{*}{ S.No } & \multirow{2}{*}{ Method } & \multirow{2}{*}{ Sample } & \multicolumn{2}{|c|}{ EGFR T790M detection rate $\%$} & \multirow[t]{2}{*}{ Study Group } \\
\hline & & & $\begin{array}{l}\text { Treatment } \\
\text { Naive/Pre-TKI }\end{array}$ & Post-TKI & \\
\hline 1 & BEAMing & Plasma $N=44$ & 4.8 & 43.5 & Taniguchi et al. [106] \\
\hline 2 & Scorpion ARMS & Plasma $N=26$ & 34.8 & 64 & Maheswaran et al. [109] \\
\hline \multirow{2}{*}{3} & ARMS & \multirow{2}{*}{ Plasma $N=135$} & 5.8 & 31.1 & \multirow{2}{*}{ Wang Z et al. [89] } \\
\hline & Digital PCR & & 25.2 & 43.0 & \\
\hline \multirow{2}{*}{4} & Mutant-enriched PCR & \multirow{2}{*}{ Plasma $N=33$} & NA & 36.4 & \multirow{2}{*}{ He et al. [74] } \\
\hline & Direct Sequencing & & NA & 6.1 & \\
\hline 5 & Cobas (Roche) & Plasma $N=23$ & 0 & 39 & \begin{tabular}{|l|l} 
Sorensen et al. [99] \\
\end{tabular} \\
\hline 6 & ddPCR & Plasma $N=49$ & - & 28.6 & Lee et al. [104] \\
\hline 7 & SABER & Plasma $N=75$ & - & 28 & Sakai et al. [120] \\
\hline 8 & ddPCR & Plasma $N=12$ & - & 41.7 & Isobe K et al. [92] \\
\hline 9 & Mutation-biased PCR & Plasma $N=58$ & - & 40 & Sueoka-Aragane N et al. [112] \\
\hline \multirow{5}{*}{10} & Mutation-biased PCR & \multirow{5}{*}{ Plasma $N=19$} & - & 53 & \multirow{5}{*}{ Nakamura T et al. [78] } \\
\hline & \begin{tabular}{|l} 
PNA-LNA PCR \\
\end{tabular} & & - & 15.7 & \\
\hline & Cycleave PCR & & - & 26.3 & \\
\hline & \begin{tabular}{|l|} 
ASO-PCR \\
\end{tabular} & & - & 31.5 & \\
\hline & Direct sequencing & & - & 31.5 & \\
\hline \multirow{2}{*}{11} & Cobas (Roche) & \multirow{2}{*}{ Plasma $N=15$} & 0 & 33.3 & \multirow{2}{*}{ Marchetti A et al. [100] } \\
\hline & NGS (Roche) & & 0 & 33.3 & \\
\hline 12 & Cobas (Roche) & Plasma $N=238$ & 0.8 & 2.01 & Mok T et al. [88] \\
\hline 13 & $\begin{array}{l}\text { NGS (Illumina) } \\
\text { Hi Seq }\end{array}$ & Plasma $N=45$ & - & 42.2 & Jin Y et al. [114] \\
\hline 14 & NGS (MiSeq) & Plasma $N=15$ & - & 60 & Paweletz et al. [95] \\
\hline 15 & Ion Torrent PGM NGS & Plasma $N=190$ & - & 16.8 & Uchida J et al. [121] \\
\hline
\end{tabular}

'- : Not reported.

considered a standard of care in NSCLC patients. Various treatments guidelines from American Society for Clinical Oncology (ASCO), College of American Pathologists (CAP), International Association for the Study of Lung Cancer (IASLC), Association for Molecular Pathology, and the US National Comprehensive Cancer Network support genetic mutation testing for treatment modalities [59-61]. The guidelines for molecular testing of EGFR mutations recommend a validated mutation method with sufficient performance characteristics with turnaround time of 2 weeks and in case of secondary or acquired resistance to TKIs the method should be sensitive enough to detect secondary mutation (T790M) [60]. Even the new European guidelines encourage coverage of exons 18-21 for mutation detection in NSCLC pateints [62]. United states FDA approved cobas (Roche) as a companion diagnostic tool for EGFR mutations detection (exon 19 deletions, L858R in exon 21 and exon 20 insertions including T790M) using tissue or plasma for TKI targeted therapies (erlotinib and osimertinib) and ARMS therascreen (Qiagen) as companion diagnostics for detecting exon 19 deletions and exon 21 (L858R) substitution mutations using tissue for afatinib selection [63].

In identifying EGFR mutations, concordance between tissue and plasma plays an important role to address the issue of liquid biopsies to serve as molecular substitute for tissue. Studies have reported 100\% specificity and sensitivity of ctDNA with concordance rate ranging from $27.5 \%-100 \%$ between ctDNA and tissue biopsy for various EGFR mutations [64-69]. A phase IV, open-label, single-arm study in Caucasian NSCLC patients $(N=652)$ demonstrated $94 \%$ concordance for EGFR mutations detected (by ARMS, Qiagen) between plasma and tumor tissue in a study evaluating efficacy and safety of gefitinib [26]. In a cross platform comparison study, the concordance for T790M mutation between plasma and ctDNA was $57 \%, 48 \%, 74 \%$ and $70 \%$ using cobas (Roche), ARMS (Qiagen), ddPCR (Bio-rad) and BEAMing dPCR, respectively between plasma ctDNA and tissue in Chinese NSCLC patients. The digital platforms outperformed to the non-digital ones in sensitivity and concordance in T790M mutation detection [70]. Additional studies on concordance of EGFR T790M 
Library Preparation

Genomic DNA

\section{$\downarrow$ Fragmentation}

Adaptors

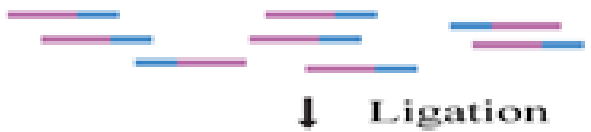

Sequencing Library

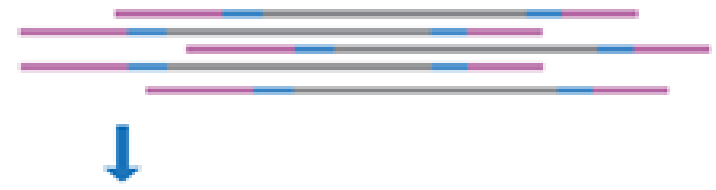

\section{Cluster Amplification}

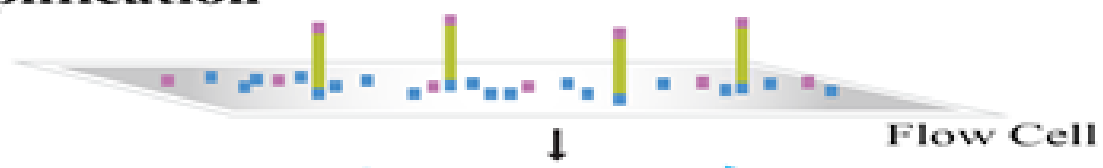

Bridge Amplification

Cycles

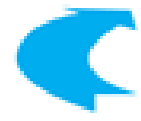

$\downarrow$
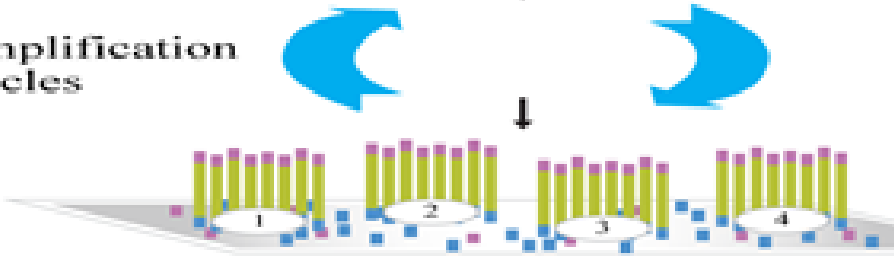

$\downarrow$

Clusters

\section{Sequencing}

Data is exported to an output file
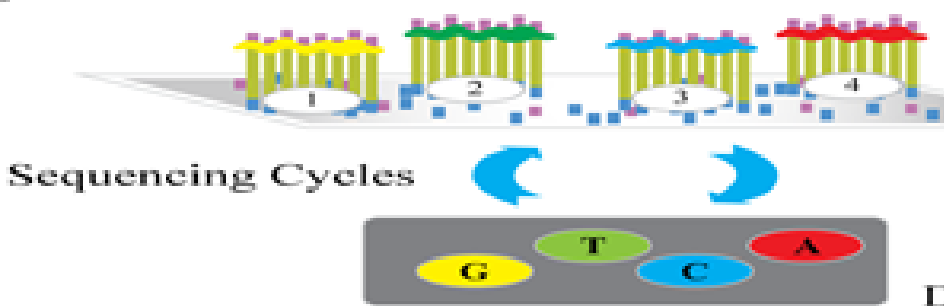

$\downarrow$

Digital Image

$$
\begin{aligned}
& \text { Cluster } 1>\text { Read 1: GAGT... } \\
& \text { Cluster } 2>\text { Read 2: TTGA... } \\
& \text { Cluster } 3>\text { Read 3: CTAG... } \\
& \text { Cluster } 4>\text { Read 4: ATAC... }
\end{aligned}
$$

Text File

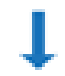

\section{Alignment $\&$ Data Anaylsis}

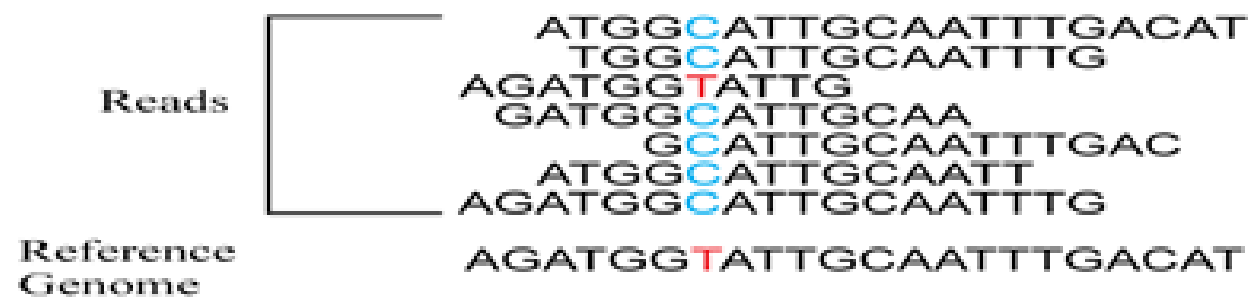

Figure 4 : Work flow of NGS (Ilumina) [39]. The methodology comprises of template preparation, sequencing, imaging and analysis. The workflow involves library preparation, cluster generations, sequencing, alignment and data analysis. Genomic DNA is fragmented and ligated using 5' and 3' adapter ligation to prepare NGS library. These fragments are amplified by PCR and gel purified. They are loaded into a flow cell and hybridisation takes place. Through bridge amplification the bound fragments are amplified into a clonal cluster. These are then sequenced base-by-base using reversible terminator based method thus eliminating sequence context specific errors. After sequencing bioinformatics software is used to align the resultant reads to reference genome thus identifying the differences. 
Table 4: Comparison of EGFR T790M detection platforms in tissue

\begin{tabular}{|c|c|c|c|c|c|}
\hline \multirow{2}{*}{ S.No } & \multirow{2}{*}{ Method } & \multirow{2}{*}{ Sample } & \multicolumn{2}{|c|}{ EGFR T790M Detection rate \% } & \multirow{2}{*}{ Study group } \\
\hline & & & \begin{tabular}{|l|} 
Treatment Naive/ \\
Pre-treatment
\end{tabular} & Post-TKI & \\
\hline 1 & Scorpion ARMS & Tissue $N=29$ & 0 & 48.3 & Chen HJ et al. [84] \\
\hline 2 & Direct sequencing & Tissue $N=14$ & 0 & 50 & Kosaka et al. [75] \\
\hline \multirow{2}{*}{3} & ARMS & \multirow{2}{*}{ Tissue $N=10$} & - & 0 & \multirow{2}{*}{ Zhang et al. [85] } \\
\hline & ddPCR & & - & 50 & \\
\hline \multirow{2}{*}{4} & Standard HRM & \multirow{2}{*}{ Tissue $N=146$} & 0 & - & \multirow{2}{*}{ Hashida et al. [107] } \\
\hline & MEC-HRM & & 13 & - & \\
\hline 5 & SABER & Tissue $N=28$ & 7 & - & Sakai et al. [120] \\
\hline 6 & Ion Torrent PGM NGS & Tissue $N=15$ & - & 60 & Masago et al. [94] \\
\hline 7 & ddPCR & Tissue $N=12$ & 83.3 & - & Isobe K et al. [92] \\
\hline \multirow{2}{*}{8} & MALDI-TOF MS & \multirow{2}{*}{ Tissue $N=54$} & 7.1 & - & \multirow{2}{*}{ Su K.Y et al. [97] } \\
\hline & NGS & & 14.3 & - & \\
\hline 9 & PNA-clamping PCR & Tissue $N=50$ & \begin{tabular}{|l|}
- \\
\end{tabular} & 68 & Costa C et al. [110] \\
\hline 10 & ddPCR & Tissue $N=78$ & 6.4 & - & Xu et al. [93] \\
\hline 11 & ACB-ARMS PCR & Tissue $N=27$ & 22.2 & - & \begin{tabular}{|l} 
Zhao J et al. [83] \\
\end{tabular} \\
\hline \multirow{2}{*}{12} & PNA-clamping PCR & \multirow{2}{*}{ Tissue $N=147$} & 8.2 & - & \multirow{2}{*}{ Oh et al. [76] } \\
\hline & Direct sequencing & & 0 & - & \\
\hline 13 & ddPCR & Tissue $N=373$ & 79.9 & - & Watanabe M et al.[105] \\
\hline \multirow{2}{*}{14} & Direct sequencing & \multirow{2}{*}{$\begin{array}{l}\text { Tissue }+ \text { other clinical } \\
\text { samples } N=280\end{array}$} & 0.3 & 1.05 & \multirow{2}{*}{ Inukai M et al. [77] } \\
\hline & Mutant-enriched PCR & & 3.5 & 3.1 & \\
\hline 15 & TaqMan PCR & Tissue $N=129$ & 35 & - & Rosell R et al. [122] \\
\hline \multirow{2}{*}{16} & SARMS & \multirow{2}{*}{ Tissue $N=38$} & 0 & - & \multirow{2}{*}{ Fujita Y et al. [86] } \\
\hline & Colony hybridisation & & 79 & - & \\
\hline 17 & Direct sequencing & Tissue $N=98$ & 2 & - & Sequist LV et al. [71] \\
\hline 18 & Direct sequencing & $\begin{array}{l}\text { Tissue+other clinical } \\
\text { samples } N=1261\end{array}$ & 0.5 & - & Wu JY et al. [79] \\
\hline 19 & $\begin{array}{l}\text { NGS } \\
\text { (Miseq/Hiseq2000/ } \\
\text { Hiseq2500) }\end{array}$ & Tissue $N=209$ & 0.48 & - & Hagemann IS et al.[108] \\
\hline 20 & LNA-PCR sequencing & Tissue $N=155$ & - & 62 & Yu HA et al. [111] \\
\hline \multirow{3}{*}{21} & Direct sequencing & \begin{tabular}{|l|} 
Tissue+other clinical \\
samples $N=69$
\end{tabular} & - & 49 & \multirow{3}{*}{ Arcila ME et al. [80] } \\
\hline & RFLP-PCR & $\begin{array}{l}\text { Tissue+other clinical } \\
\text { samples } N=45\end{array}$ & - & 53 & \\
\hline & LNA-PCR sequencing & $\begin{array}{l}\text { Tissue+other clinical } \\
\text { samples } N=64\end{array}$ & - & 70 & \\
\hline 22 & TaqMan PCR & $\begin{array}{l}\text { Tissue+other clinical } \\
\text { samples } N=15\end{array}$ & - & 40 & $\begin{array}{l}\text { Molina-Vila MA et al. } \\
{[123]}\end{array}$ \\
\hline 23 & AMRS & Tissue $N=609$ & 0.8 & - & Mok TS et al. [87] \\
\hline 24 & Direct sequencing & Tissue $N=74$ & - & 1.35 & Soh J et al. [81] \\
\hline 25 & $\begin{array}{l}\text { Cobas(Roche)/ARMS } \\
\text { (Qiagen) }\end{array}$ & Tissue $N=148$ & - & 53 & Sequist LV et al. [101] \\
\hline 26 & Cobas (Roche) & Tissue $N=222$ & - & 62 & \begin{tabular}{|l|} 
Janne PA et al. [21] \\
\end{tabular} \\
\hline 27 & ARMS & Tissue $N=134$ & 6.8 & 28.4 & Yu J et al. [124] \\
\hline 28 & NGS (MiSeq) & Tissue $=15$ & - & \begin{tabular}{|l|l|}
73.3 \\
\end{tabular} & Paweletz et al. [95] \\
\hline 29 & $\begin{array}{l}\text { NGS (AmpliSeq cancer } \\
\text { hotspot panel v2) }\end{array}$ & Tissue $\mathrm{N}=43$ & - & 79 & Belchis DA et al. [96] \\
\hline
\end{tabular}

‘-‘: not reported 
mutation detection in tumor and plasma are summarized in Table 2. These studies report wide range of concordance range $48-94 \%$, sensitivities $(29-81.8 \%)$ and specificities (83-100\%). This variability in concordance, sensitivities and specificities are heavily technology driven.

Several studies have demonstrated use of various platforms for EGFR T790M detection both in plasma (Table 3) and tissue samples (Table 4). Direct sequencing is widely used in EGFR mutation detection. Studies have reported detection limit of direct sequencing to be around $25-30 \%$. This method is complex, time consuming and not standardized in terms of clinical laboratory practice [71-73]. Although, direct sequencing has drawbacks with low sensitivity, several studies have reported use of direct sequencing in detecting EGFR T790M with detection rate ranging from $0-50 \%$. This disparity could be attributed to the low abundance of T790M mutation (due to less sensitivity of the technique mutation is not detected) and also to small sample size (instances where higher detection rates are reported) $[71,74-81]$. Some studies compared direct sequencing with other techniques (mutant-enriched PCR, RFLP-PCR, LNA-PCR, Mutation-biased PCR) in T790M mutation detection and demonstrated higher detection rates by other sensitive methods [74, 76-78, 80].

ARMS is another most commonly used method for EGFR mutation testing both in plasma and tissue [26, 70,76-78, 82-88]. Though it produces good specificity, it lacks sensitivity when compared to HRM, ddPCR, cobas, colony hybridization and BEAMing [70, 83, 85, 86, 89]. Another study used a method combining allele-specific competitive blocker (ACB) with TaqMan quantitative PCR ARMS called ACB-ARMS PCR for EGFR T790M testing and found $22.2 \%$ T790M mutation detection rate as compared to scorpion ARMS (0.0\%) in tissue samples [83].

Quantification platforms like ddPCR and NGS are also widely used in T790M mutation detection especially in dynamic monitoring during TKI therapy. Ishii et al. reported high sensitivity (82\%) and specificity (86\%) of digital PCR (bio-rad) in detecting T790M mutation using plasma ctDNA with concordance of $83.3 \%$ with tumor tissue. Qualitatively digital PCR was more sensitive than ARMS in detecting T790M mutation both in pre- and post-TKI plasma samples $31.1 \%$ vs $5.5 \%(P<0.001)$ and $43.0 \%$ vs $25.2 \%(P=0.001)$, respectively [90]. Quantitative dynamic monitoring of T790M mutation by digital PCR is useful to predicted the clinical outcomes of EGFR TKIs using plasma ctDNA, as serial rebiopsies using tissue is practically impossible [89-92]. In detecting T790M mutation ddPCR has high sensitivity and specificity compared to cobas, BEAMing, ARMS and conventional PCR [70, 85, 93].

Targeted NGS using Ion Torrent Personal Genome Machine detected T790M resistant mutation in $60 \%$ of the cases which were not diagnosed by other conventional platforms. In addition to EGFR mutations other oncogenic mutations were detected which may play a role in TKIs resistance. This high throughput analysis of NGS elucidates the importance of such analysis in targeted therapy [94]. Two other studies also demonstrated the use of targeted NGS in detection of resistant mutations both in tissue and plasma even at low abundance rate $[95,96]$. Mass spectrometry (MALDI-TOF-MS) compared to direct sequencing yielded good results with detection rates of 83.3 and $33.3 \%$ respectively for T790M mutation in tissue. The results of MALDI-TOF-MS showed good correlation with NGS [97].

Cobas is a semi-quantitative method used frequently in mutational analysis using tissue or plasma $[21,70,87$, 98-101]. Thress et al. reported concordance of $78.6 \%$ between tumor tissue and plasma using this method, another study indicated a positive percentage agreement of $64 \%$ between tissue and plasma [70, 98]. Quantification of T790M mutation using cobas and NGS significant correlation between the two tests $(P<0.001)$ with concordance rate of $95 \%$. The sensitivity and specificity of cobas and NGS was $72 \%$ and $100 \%$ to that of $74 \%$ and $100 \%$, respectively. Though PCR based techniques can identify only the known mutations, they are preferred over NGS due to the advantages attributed to their ease, turnaround time and cost [100].

\section{PREVALENCE OFT790M IN PRE-TKI AND POST-TKI NSCLC PATIENTS}

Ethnic variations are observed in EGFR mutations. The mutation rate among east Asians is 30-40\% among east Asians when compared to $5-13 \%$ in Caucasians, signifying the importance of molecular analysis in east Asian popluations [102]. Among the EGFR mutations, the T790M mutation occurs in less than $5 \%$ of the untreated EGFR mutated tumors and occurs to about $50 \%$ of the EGFR mutated tumors that acquire resistance to the first generation TKIs $[12,77,103]$. Tables 3 and 4 summarise the prevalence of T790M mutations in pre- and postTKI NSCLC patients using tissue and plasma samples. Though for most of the studies patients ethnic details are not reported. Dividing all the studies into Asian and nonAsian. Asians studies have used cobas, ddPCR, BEAMing, ARMS, direct sequencing and Ion torrent PGM platforms for detecting T790M mutation $[21,70,71,75,81,84,87$, $88,94,101,104,105]$. The frequency of T790M mutation ranged from $0-35 \%$ with most of the studies reporting less than 5\% before TKI administration in NSCLC [71, 75-77, 79, 84, 86-88, 99, 100, 106-108]. Three studies reported more than $50 \%$ of $\mathrm{T} 790 \mathrm{M}$ mutation in patients before TKI $[86,92,105]$. This high frequency could be attributed to small sample size in one of the studies [92] and to high sensitivity of the detection methods (ddPCR and colony hybridisation) used to detect low abundance T790M mutation in the other two studies $[86,105]$. The incidence of T790M mutation in after TKI ranged from 
$0-70 \%$ with most studies reporting around $50 \%$ of this resistant mutation in NSCLC patients $[21,74,75,78,80$, $81,84,85,87,88,94,101,104,106,109-111]$. This low detection rates in few of the post-TKI studies of T790M mutation rate could be attributed to the technology used for detection (direct sequencing) and heterogeneity of the tissue sample [77, 81].

Non-Asian studies used ARMS, cobas and PNAPCR for mutation detection [26, 99, 107, 111]. The incidence of post-TKI T790M around 50-60\% [99, $110,111]$. The percentage of T790M mutation directly correlates with the treatment duration of the first and second line TKI for acquiring resistance to these TKIs. The variation in the rate may also be attributed to the differences in sensitivities of the testing platforms. The rate of T790M detected in tissue and plasma also varies as evident from the various studies (Table 3 and Table 4). Moreover, Sueoka-Aragane et al. demonstrated that T790M mutation was frequently detected in certain subgroups of patients like smokers, males, in patients with exon 19 deletion and in patients with new lesions [112].

Several studies demonstrated the prevalence of T790M in Chinese populations using various technologies. Zhao et al validated three platforms RTD-PCR sequencing, TaqMan probe PCR and Sequenom MassArray for specific detection of EGFR T790M mutation and found that all three platforms detected T790M in seven cases from 78 tissue samples [113]. The ddPCR showed better sensitivity and specificity over qPCR in detecting EGFR mutations in tissue samples and it detected T790M mutation (6.4\%) which were missed by qPCR in pre-TKI patients [93]. ARMS detected T790M mutation in $48.3 \%$ in post-TKI patients whereas no mutation was detected in pre-TKI Chinese NSCLC patients [84]. Another study reported T790M mutation in $36.1 \%$ in TKI resistant patients using NGS [114].

\section{CONCLUSION}

In this review, we compared various companion diagnostic platforms for EGFR T790M testing. Multiple platforms like cobas, BEAMing, ddPCR and NGS are capable of detecting EGFR TKI resistant mutations in NSCLC patients though they differ in their sensitivity, specificity and turnaround time. In cases that demand quantification of mutation BEAMing, ddPCR and NGS could take a lead. More prospective studies to monitor the EGFR T790M in plasma ctDNA during or after EGFR TKI treatment are warranted.

Overall the data suggests that plasma testing is useful compared to tissue especially in patients with EGFR T790M resistant mutations where continuous monitoring is mandate. Other bodily fluids can also be investigated as potential alternatives in real-time monitoring for targeted therapy in EGFR mutated NSCLCs.

\section{ACKNOWLEDGMENTS}

The authors acknowledge Dr Anuradha Nalli (PhD) and Dr Amit Bhat (PhD) (Indegene, Bangalore, India) for providing medical writing support and technical assistance in the development of this manuscript.

\section{CONFLICTS OF INTEREST}

The authors have no conflict of interest to declare.

\section{REFERENCES}

1. Bai H, Mao L, Wang HS, Zhao J, Yang L, An TT, Wang X, Duan CJ, Wu NM, Guo ZQ, Liu YX, Liu HN, Wang YY, et al. Epidermal growth factor receptor mutations in plasma DNA samples predict tumor response in Chinese patients with stages IIIB to IV non-small-cell lung cancer. J Clin Oncol. 2009; 27: 2653-9.

2. Franklin WA, Veve R, Hirsch FR, Helfrich BA, Bunn PA Jr. Epidermal growth factor receptor family in lung cancer and premalignancy. Semin Oncol. 2002; 29: 3-14.

3. Lynch TJ, Bell DW, Sordella R, Gurubhagavatula S, Okimoto RA, Brannigan BW, Harris PL, Haserlat SM, Supko JG, Haluska FG, Louis DN, Christiani DC, Settleman $\mathrm{J}$, et al. Activating mutations in the epidermal growth factor receptor underlying responsiveness of non-small-cell lung cancer to gefitinib. N Engl J Med. 2004; 350: 2129-39.

4. Paez JG, Janne PA, Lee JC, Tracy S, Greulich H, Gabriel S, Herman P, Kaye FJ, Lindeman N, Boggon TJ, Naoki K, Sasaki H, Fujii Y, et al. EGFR mutations in lung cancer: correlation with clinical response to gefitinib therapy. Science. 2004; 304: 1497-500.

5. Shigematsu H, Lin L, Takahashi T, Nomura M, Suzuki M, Wistuba II, Fong KM, Lee H, Toyooka S, Shimizu N, Fujisawa T, Feng Z, Roth JA, et al. Clinical and biological features associated with epidermal growth factor receptor gene mutations in lung cancers. J Natl Cancer Inst. 2005; 97: 339-46.

6. Tracy S, Mukohara T, Hansen M, Meyerson M, Johnson BE, Janne PA. Gefitinib induces apoptosis in the EGFRL858R non-small-cell lung cancer cell line H3255. Cancer Res. 2004; 64: 7241-4.

7. Wang J, Ramakrishnan R, Tang Z, Fan W, Kluge A, Dowlati A, Jones RC, Ma PC. Quantifying EGFR alterations in the lung cancer genome with nanofluidic digital PCR arrays. Clin Chem. 2010; 56: 623-32.

8. Maemondo M, Inoue A, Kobayashi K, Sugawara S, Oizumi S, Isobe H, Gemma A, Harada M, Yoshizawa H, Kinoshita I, Fujita Y, Okinaga S, Hirano H, et al. Gefitinib or chemotherapy for non-small-cell lung cancer with mutated EGFR. N Engl J Med. 2010; 362: 2380-8.

9. Rosell R, Carcereny E, Gervais R, Vergnenegre A, Massuti B, Felip E, Palmero R, Garcia-Gomez R, Pallares C, 
Sanchez JM, Porta R, Cobo M, Garrido P, et al. Erlotinib versus standard chemotherapy as first-line treatment for European patients with advanced EGFR mutation-positive non-small-cell lung cancer (EURTAC): a multicentre, openlabel, randomised phase 3 trial. Lancet Oncol. 2012; 13: 239-46.

10. Fukuoka M, Yano S, Giaccone G, Tamura T, Nakagawa K, Douillard JY, Nishiwaki Y, Vansteenkiste J, Kudoh S, Rischin D, Eek R, Horai T, Noda K, et al. Multi-institutional randomized phase II trial of gefitinib for previously treated patients with advanced non-small-cell lung cancer (The IDEAL 1 Trial) [corrected]. J Clin Oncol. 2003; 21: 2237 46.

11. Kris MG, Natale RB, Herbst RS, Lynch TJ Jr, Prager D, Belani CP, Schiller JH, Kelly K, Spiridonidis H, Sandler A, Albain KS, Cella D, Wolf MK, et al. Efficacy of gefitinib, an inhibitor of the epidermal growth factor receptor tyrosine kinase, in symptomatic patients with non-small cell lung cancer: a randomized trial. JAMA. 2003; 290: 2149-58.

12. Pao W, Miller VA, Politi KA, Riely GJ, Somwar R, Zakowski MF, Kris MG, Varmus H. Acquired resistance of lung adenocarcinomas to gefitinib or erlotinib is associated with a second mutation in the EGFR kinase domain. PLoS Med. 2005; 2: e73.

13. Gazdar AF. Activating and resistance mutations of EGFR in non-small-cell lung cancer: role in clinical response to EGFR tyrosine kinase inhibitors. Oncogene. 2009; 28 : S24-31.

14. Oxnard GR, Arcila ME, Chmielecki J, Ladanyi M, Miller VA, Pao W. New strategies in overcoming acquired resistance to epidermal growth factor receptor tyrosine kinase inhibitors in lung cancer. Clin Cancer Res. 2011; 17: 5530-7.

15. Ayoola A, Barochia A, Belani K, Belani CP. Primary and acquired resistance to epidermal growth factor receptor tyrosine kinase inhibitors in non-small cell lung cancer: an update. Cancer Invest. 2012; 30: 433-46.

16. Engelman JA, Zejnullahu K, Gale CM, Lifshits E, Gonzales AJ, Shimamura T, Zhao F, Vincent PW, Naumov GN, Bradner JE, Althaus IW, Gandhi L, Shapiro GI, et al. PF00299804, an irreversible pan-ERBB inhibitor, is effective in lung cancer models with EGFR and ERBB2 mutations that are resistant to gefitinib. Cancer Res. 2007; 67: 11924-32.

17. Miller VA, Hirsh V, Cadranel J, Chen YM, Park K, Kim SW, Zhou C, Su WC, Wang M, Sun Y, Heo DS, Crino L, Tan EH, et al. Afatinib versus placebo for patients with advanced, metastatic non-small-cell lung cancer after failure of erlotinib, gefitinib, or both, and one or two lines of chemotherapy (LUX-Lung 1): a phase 2b/3 randomised trial. Lancet Oncol. 2012; 13: 528-38.

18. Li D, Ambrogio L, Shimamura T, Kubo S, Takahashi M, Chirieac LR, Padera RF, Shapiro GI, Baum A, Himmelsbach F, Rettig WJ, Meyerson M, Solca F, et al. BIBW2992, an irreversible EGFR/HER2 inhibitor highly effective in preclinical lung cancer models. Oncogene. 2008; 27: 4702-11.

19. Janne PA, Boss DS, Camidge DR, Britten CD, Engelman JA, Garon EB, Guo F, Wong S, Liang J, Letrent S, Millham R, Taylor I, Eckhardt SG, et al. Phase I dose-escalation study of the pan-HER inhibitor, PF299804, in patients with advanced malignant solid tumors. Clin Cancer Res. 2011; 17: 1131-9.

20. Yap TA, Vidal L, Adam J, Stephens P, Spicer J, Shaw H, Ang J, Temple G, Bell S, Shahidi M, UttenreutherFischer M, Stopfer P, Futreal A, et al. Phase I trial of the irreversible EGFR and HER2 kinase inhibitor BIBW 2992 in patients with advanced solid tumors. J Clin Oncol. 2010; 28: 3965-72.

21. Janne PA, Yang JC, Kim DW, Planchard D, Ohe Y, Ramalingam SS, Ahn MJ, Kim SW, Su WC, Horn L, Haggstrom D, Felip E, Kim JH, et al. AZD9291 in EGFR inhibitor-resistant non-small-cell lung cancer. N Engl J Med. 2015; 372: 1689-99.

22. Cross DA, Ashton SE, Ghiorghiu S, Eberlein C, Nebhan CA, Spitzler PJ, Orme JP, Finlay MR, Ward RA, Mellor MJ, Hughes G, Rahi A, Jacobs VN, et al. AZD9291, an irreversible EGFR TKI, overcomes T790M-mediated resistance to EGFR inhibitors in lung cancer. Cancer Discov. 2014; 4: 1046-61.

23. Fisher R, Pusztai L, Swanton C. Cancer heterogeneity: implications for targeted therapeutics. Br J Cancer. 2013; 108: 479-85.

24. Weber B, Meldgaard P, Hager H, Wu L, Wei W, Tsai J, Khalil A, Nexo E, Sorensen BS. Detection of EGFR mutations in plasma and biopsies from non-small cell lung cancer patients by allele-specific PCR assays. BMC Cancer. 2014; 14: 294.

25. Douillard JY, Ostoros G, Cobo M, Ciuleanu T, Cole R, McWalter G, Walker J, Dearden S, Webster A, Milenkova T, McCormack R. Gefitinib treatment in EGFR mutated caucasian NSCLC: circulating-free tumor DNA as a surrogate for determination of EGFR status. J Thorac Oncol. 2014; 9: 1345-53.

26. Douillard JY, Ostoros G, Cobo M, Ciuleanu T, McCormack R, Webster A, Milenkova T. First-line gefitinib in Caucasian EGFR mutation-positive NSCLC patients: a phase-IV, open-label, single-arm study. Br J Cancer. 2014; 110: 55-62.

27. Punnoose EA, Atwal S, Liu W, Raja R, Fine BM, Hughes BG, Hicks RJ, Hampton GM, Amler LC, Pirzkall A, Lackner MR. Evaluation of circulating tumor cells and circulating tumor DNA in non-small cell lung cancer: association with clinical endpoints in a phase II clinical trial of pertuzumab and erlotinib. Clin Cancer Res. 2012; 18: 2391-401.

28. Cobas R. Roche mutation tests. WEB. 2015. Available from http://egfrmutationtestv2.roche.com/benefits/.

29. Beijing Key Laboratory of Hematopoietic Stem Cell 
Transplantation. ARMS PCR in Molecular pathologyMutation testing made simple. 2017.

30. Newton CR, Graham A, Heptinstall LE, Powell SJ, Summers C, Kalsheker N, Smith JC, Markham AF. Analysis of any point mutation in DNA. The amplification refractory mutation system (ARMS). Nucleic Acids Res. 1989; 17: 2503-16.

31. Whitcombe D, Theaker J, Guy SP, Brown T, Little S. Detection of PCR products using self-probing amplicons and fluorescence. Nat Biotechnol. 1999; 17: 804-7.

32. therascreenr EGFR RGQ PCR Kit Handbook. WEB. 2013. Available from https://www.google.co.in/url? $\mathrm{sa}=\mathrm{t} \& \mathrm{rct}=\mathrm{j} \& \mathrm{q}=\&$ esrc $=\mathrm{s} \&$ source $=$ web $\& \mathrm{~cd}=2 \& \mathrm{cad}=$ rja\&uact $=8 \&$ ved $=0$ ahUKEwik-sj1z_LNAhUJ5WM KHUx3D6MQFggiMAE\&url=https $\% 3 \mathrm{~A} \% 2 \mathrm{~F} \% 2 \mathrm{Fw}$ ww.qiagen.com $\% 2 \mathrm{Fch} \% 2 \mathrm{Fresources} \% 2 \mathrm{Fdownload}$. aspx\%3Fid\%3Ddb794cae-999b-4362-aba3-455ebfd807a5 \%26lang\%3Den\&usg=AFQjCNEpCgF-1JMNDBi55fvHpk dyi2LG3A\&bvm=bv.126993452_,_d.cGc.

33. therascreen EGFR RGQ PCR Kit version 2. WEB. 2016. Available from https://www.qiagen.com/de/shop-old/assaytechnologies/complete-assay-kits/personalized-healthcare/ therascreen-egfr-rgq-pcr-kit-v2/.

34. AmoyDxr EGFR Mutation Detection Test (CE-IVD). WEB. 2016. Available from http://www.gen-era.com.tr/belgeler/ AmoyDx\%20EGFR\%20Mutation\%20Det.\%20Kit\%20 Sell\%20Sheet.pdf.

35. Pohl G, Shih I. Principle and applications of digital PCR. Expert Rev Mol Diagn. 2004; 4: 41-7.

36. BEAMing DIGITAL PCR TECHNOLOGY. WEB. 2016. Available from http://www.sysmex-inostics.com/fileadmin/ media/f121/Fact_sheets/Sysmex_Inostics_BEAMing Digital_PCR_Technology_en.pdf.

37. Droplet Digital PCR Technology. WEB. 2016. Available from http:/www.bio-rad.com/webroot/web/pdf/lsr/ literature/Bulletin_6407.pdf.

38. Supported Protocol: Getting Started with the QuantStudio T 3D Digital PCR System . WEB. 2016. Available from http:// tools.thermofisher.com/content/sfs/manuals/MAN0009821. pdf.

39. An Introduction to Next-Generation sequencing Technology. WEB. 2016. Available from http://www. illumina.com/content/dam/illumina-marketing/documents/ products/illumina_sequencing_introduction.pdf.

40. illumina. System Specification Sheet: Sequencing. WEB. 2016. Available from https://www.thermofisher.com/in/en/ home/brands/ion-torrent.html.

41. Targeted Sequencing by Ion Torrent Next-Generation Sequencing. WEB. 2016. Available from https://www. thermofisher.com/in/en/home/brands/ion-torrent.html.

42. Targeted Sequencing for Cancer Mutation Detection. WEB. 2016. Available from https:/www.thermofisher.com/in/ en/home/life-science/cancer-research/cancer-genomics/ targeted-sequencing-cancer-mutation-detection.html.
43. Oncomine Cell-Free DNA Assays for Liquid Biopsy Clinical Research. WEB. 2016. Available from https:// www.thermofisher.com/in/en/home/life-science/cancerresearch/cancer-genomics/targeted-sequencing-cancermutation-detection.html.

44. Kimura H, Suminoe M, Kasahara K, Sone T, Araya T, Tamori S, Koizumi F, Nishio K, Miyamoto K, Fujimura M, Nakao S. Evaluation of epidermal growth factor receptor mutation status in serum DNA as a predictor of response to gefitinib (IRESSA). Br J Cancer. 2007; 97: 778-84.

45. Yung TK, Chan KC, Mok TS, Tong J, To KF, Lo YM. Single-molecule detection of epidermal growth factor receptor mutations in plasma by microfluidics digital PCR in non-small cell lung cancer patients. Clin Cancer Res. 2009; 15: 2076-84.

46. Leary RJ, Sausen M, Kinde I, Papadopoulos N, Carpten JD, Craig D, O'Shaughnessy J, Kinzler KW, Parmigiani G, Vogelstein B, Diaz LA Jr, Velculescu VE. Detection of chromosomal alterations in the circulation of cancer patients with whole-genome sequencing. Sci Transl Med. 2012; 4: 162ra154.

47. Chan KC, Jiang P, Zheng YW, Liao GJ, Sun H, Wong J, Siu SS, Chan WC, Chan SL, Chan AT, Lai PB, Chiu RW, Lo YM. Cancer genome scanning in plasma: detection of tumor-associated copy number aberrations, singlenucleotide variants, and tumoral heterogeneity by massively parallel sequencing. Clin Chem. 2013; 59: 211-24.

48. Ichihara E, Lovly CM. Shades of T790M: Intratumor Heterogeneity in EGFR-Mutant Lung Cancer. Cancer Discov. 2015; 5: 694-6.

49. Piotrowska Z, Niederst MJ, Karlovich CA, Wakelee HA, Neal JW, Mino-Kenudson M, Fulton L, Hata AN, Lockerman EL, Kalsy A, Digumarthy S, Muzikansky A, Raponi M, et al. Heterogeneity Underlies the Emergence of EGFRT790 Wild-Type Clones Following Treatment of T790M-Positive Cancers with a Third-Generation EGFR Inhibitor. Cancer Discov. 2015; 5: 713-22.

50. Wei F, Lin CC, Joon A, Feng Z, Troche G, Lira ME, Chia D, Mao M, Ho CL, Su WC, Wong DT. Noninvasive salivabased EGFR gene mutation detection in patients with lung cancer. Am J Respir Crit Care Med. 2014; 190: 1117-26.

51. Hung MS, Lin CK, Leu SW, Wu MY, Tsai YH, Yang CT. Epidermal growth factor receptor mutations in cells from non-small cell lung cancer malignant pleural effusions. Chang Gung Med J. 2006; 29: 373-9.

52. Huang MJ, Lim KH, Tzen CY, Hsu HS, Yen Y, Huang BS. EGFR mutations in malignant pleural effusion of nonsmall cell lung cancer: a case report. Lung Cancer. 2005; 49: 413-5.

53. Zhang X, Zhao Y, Wang M, Yap WS, Chang AY. Detection and comparison of epidermal growth factor receptor mutations in cells and fluid of malignant pleural effusion in non-small cell lung cancer. Lung Cancer. 2008; 60: 175-82.

54. Levitan D. Plasma, Urine Tests Can Help Detect EGFR 
T790M Mutations in NSCLC. WEB. 2016. Available from http://www.cancernetwork.com/asco-2016-lung-cancer/ plasma-urine-tests-can-help-detect-egfr-t790m-mutationsnsclc.

55. Hatim Husain KK, Cecile Rose T. Kinetic monitoring of EGFR T790M in urinary circulating tumor DNA to predict radiographic progression and response in patients with metastatic lung adenocarcinoma. J Clin Oncol. 2016; 33: 8081-8081.

56. Kuznar W. Urine Biopsies Detect Early Mutations in Patients with Advanced Cancers. Am Health Drug Benefits. 2015; 8: 38 .

57. Husain H, Kosco K. Dynamic changes in EGFR mutation circulating tumor DNA in urine on anti-EGFR therapy. J Thorac Oncol. 2015; 10:9.

58. Reckamp KL, Melnikova VO, Karlovich C, Sequist LV, Camidge DR, Wakelee H, Perol M, Oxnard GR, Kosco K, Croucher P, Samuelsz E, Vibat CR, Guerrero S, et al. A Highly Sensitive and Quantitative Test Platform for Detection of NSCLC EGFR Mutations in Urine and Plasma. J Thorac Oncol. 2016; 11: 1690-700.

59. Ettinger DS, Wood DE, Akerley W, Bazhenova LA, Borghaei H, Camidge DR, Cheney RT, Chirieac LR, D’Amico TA, Demmy TL, Dilling TJ, Dobelbower MC, Govindan R, et al. Non-Small Cell Lung Cancer, Version 6.2015. J Natl Compr Canc Netw. 2015; 13: 515-24.

60. Lindeman NI, Cagle PT, Beasley MB, Chitale DA, Dacic S, Giaccone G, Jenkins RB, Kwiatkowski DJ, Saldivar JS, Squire J, Thunnissen E, Ladanyi M, College of American Pathologists International Association for the Study of Lung Cancer and Association for Molecular Pathology. Molecular testing guideline for selection of lung cancer patients for EGFR and ALK tyrosine kinase inhibitors: guideline from the College of American Pathologists, International Association for the Study of Lung Cancer, and Association for Molecular Pathology. J Mol Diagn. 2013; 15: 415-53.

61. Masters GA, Temin S, Azzoli CG, Giaccone G, Baker S Jr, Brahmer JR, Ellis PM, Gajra A, Rackear N, Schiller JH, Smith TJ, Strawn JR, Trent D, et al. Systemic Therapy for Stage IV Non-Small-Cell Lung Cancer: American Society of Clinical Oncology Clinical Practice Guideline Update. J Clin Oncol. 2015; 33: 3488-515.

62. Kerr KM, Bubendorf L, Edelman MJ, Marchetti A, Mok T, Novello S, O’Byrne K, Stahel R, Peters S, Felip E. Second ESMO consensus conference on lung cancer: pathology and molecular biomarkers for non-small-cell lung cancer. Ann Oncol. 2014; 25: 1681-90.

63. List of Cleared or Approved Companion Diagnostic Devices (In Vitro and Imaging Tools). WEB. 2016. Available from http:/www.fda.gov/MedicalDevices/ ProductsandMedicalProcedures/InVitroDiagnostics/ ucm301431.htm.

64. Kim HR, Lee SY, Hyun DS, Lee MK, Lee HK, Choi CM, Yang SH, Kim YC, Lee YC, Kim SY, Jang SH, Lee JC, Lee $\mathrm{KY}$. Detection of EGFR mutations in circulating free DNA by PNA-mediated PCR clamping. J Exp Clin Cancer Res. 2013; 32: 50 .

65. He C, Liu M, Zhou C, Zhang J, Ouyang M, Zhong N, Xu J. Detection of epidermal growth factor receptor mutations in plasma by mutant-enriched PCR assay for prediction of the response to gefitinib in patients with non-small-cell lung cancer. Int J Cancer. 2009; 125: 2393-9.

66. Mack PC, Holland WS, Burich RA, Sangha R, Solis LJ, Li Y, Beckett LA, Lara PN Jr, Davies AM, Gandara DR. EGFR mutations detected in plasma are associated with patient outcomes in erlotinib plus docetaxel-treated nonsmall cell lung cancer. J Thorac Oncol. 2009; 4: 1466-72.

67. Jiang B, Liu F, Yang L, Zhang W, Yuan H, Wang J, Huang G. Serum detection of epidermal growth factor receptor gene mutations using mutant-enriched sequencing in Chinese patients with advanced non-small cell lung cancer. J Int Med Res. 2011; 39: 1392-401.

68. Zhang H, Liu D, Li S, Zheng Y, Yang X, Li X, Zhang Q, Qin N, Lu J, Ren-Heidenreich L, Yang H, Wu Y, Zhang X, et al. Comparison of EGFR signaling pathway somatic DNA mutations derived from peripheral blood and corresponding tumor tissue of patients with advanced nonsmall-cell lung cancer using liquidchip technology. J Mol Diagn. 2013; 15: 819-26.

69. Xu F, Wu J, Xue C, Zhao Y, Jiang W, Lin L, Wu X, Lu Y, Bai H, Xu J, Zhu G, Zhang L. Comparison of different methods for detecting epidermal growth factor receptor mutations in peripheral blood and tumor tissue of non-small cell lung cancer as a predictor of response to gefitinib. Onco Targets Ther. 2012; 5: 439-47.

70. Thress KS, Brant R, Carr TH, Dearden S, Jenkins S, Brown H, Hammett T, Cantarini M, Barrett JC. EGFR mutation detection in ctDNA from NSCLC patient plasma: A crossplatform comparison of leading technologies to support the clinical development of AZD9291. Lung Cancer. 2015; 90: 509-15.

71. Sequist LV, Martins RG, Spigel D, Grunberg SM, Spira A, Janne PA, Joshi VA, McCollum D, Evans TL, Muzikansky A, Kuhlmann GL, Han M, Goldberg JS, et al. First-line gefitinib in patients with advanced non-small-cell lung cancer harboring somatic EGFR mutations. J Clin Oncol. 2008; 26: 2442-9.

72. Eberhard DA, Giaccone G, Johnson BE. Biomarkers of response to epidermal growth factor receptor inhibitors in Non-Small-Cell Lung Cancer Working Group: standardization for use in the clinical trial setting. J Clin Oncol. 2008; 26: 983-94.

73. Penzel R, Sers C, Chen Y, Lehmann-Muhlenhoff U, Merkelbach-Bruse S, Jung A, Kirchner T, Buttner R, Kreipe HH, Petersen I, Dietel M, Schirmacher P. EGFR mutation detection in NSCLC--assessment of diagnostic application and recommendations of the German Panel for Mutation Testing in NSCLC. Virchows Arch. 2011; 458: 95-8.

74. He C, Zheng L, Xu Y, Liu M, Li Y, Xu J. Highly sensitive and noninvasive detection of epidermal growth factor 
receptor T790M mutation in non-small cell lung cancer. Clin Chim Acta. 2013; 425: 119-24.

75. Kosaka T, Yatabe Y, Endoh H, Yoshida K, Hida T, Tsuboi M, Tada H, Kuwano H, Mitsudomi T. Analysis of epidermal growth factor receptor gene mutation in patients with non-small cell lung cancer and acquired resistance to gefitinib. Clin Cancer Res. 2006; 12: 5764-9.

76. Oh JE, An CH, Yoo NJ, Lee SH. Detection of low-level EGFR T790M mutation in lung cancer tissues. APMIS. 2011; 119: 403-11.

77. Inukai M, Toyooka S, Ito S, Asano H, Ichihara S, Soh J, Suehisa H, Ouchida M, Aoe K, Aoe M, Kiura K, Shimizu N, Date H. Presence of epidermal growth factor receptor gene T790M mutation as a minor clone in non-small cell lung cancer. Cancer Res. 2006; 66: 7854-8.

78. Nakamura T, Sueoka-Aragane N, Iwanaga K, Sato A, Komiya K, Abe T, Ureshino N, Hayashi S, Hosomi T, Hirai M, Sueoka E, Kimura S. A noninvasive system for monitoring resistance to epidermal growth factor receptor tyrosine kinase inhibitors with plasma DNA. J Thorac Oncol. 2011; 6: 1639-48.

79. Wu JY, Yu CJ, Chang YC, Yang CH, Shih JY, Yang PC. Effectiveness of tyrosine kinase inhibitors on "uncommon" epidermal growth factor receptor mutations of unknown clinical significance in non-small cell lung cancer. Clin Cancer Res. 2011; 17: 3812-21.

80. Arcila ME, Oxnard GR, Nafa K, Riely GJ, Solomon SB, Zakowski MF, Kris MG, Pao W, Miller VA, Ladanyi M. Rebiopsy of lung cancer patients with acquired resistance to EGFR inhibitors and enhanced detection of the T790M mutation using a locked nucleic acid-based assay. Clin Cancer Res. 2011; 17: 1169-80.

81. Soh J, Toyooka S, Ichihara S, Fujiwara Y, Hotta K, Suehisa H, Kobayashi N, Ichimura K, Aoe K, Aoe M, Kiura K, Date H. Impact of HER2 and EGFR gene status on gefitinibtreated patients with nonsmall-cell lung cancer. Int J Cancer. 2007; 121: 1162-7.

82. Luo J, Shen L, Zheng D. Diagnostic value of circulating free DNA for the detection of EGFR mutation status in NSCLC: a systematic review and meta-analysis. Sci Rep. 2014; 4: 6269.

83. Zhao J, Feng HH, Zhao JY, Liu LC, Xie FF, Xu Y, Chen MJ, Zhong W, Li LY, Wang HP, Zhang LI, Xiao YI, Chen WJ, et al. A sensitive and practical method to detect the T790M mutation in the epidermal growth factor receptor. Oncol Lett. 2016; 11: 2573-9.

84. Chen HJ, Mok TS, Chen ZH, Guo AL, Zhang XC, Su J, Wu YL. Clinicopathologic and molecular features of epidermal growth factor receptor T790M mutation and c-MET amplification in tyrosine kinase inhibitor-resistant Chinese non-small cell lung cancer. Pathol Oncol Res. 2009; 15: $651-8$.

85. Zhang BO, Xu CW, Shao Y, Wang HT, Wu YF, Song YY, Li XB, Zhang Z, Wang WJ, Li LQ, Cai CL. Comparison of droplet digital PCR and conventional quantitative PCR for measuring EGFR gene mutation. Exp Ther Med. 2015; 9: 1383-8.

86. Fujita Y, Suda K, Kimura H, Matsumoto K, Arao T, Nagai T, Saijo N, Yatabe Y, Mitsudomi T, Nishio K. Highly sensitive detection of EGFR T790M mutation using colony hybridization predicts favorable prognosis of patients with lung cancer harboring activating EGFR mutation. J Thorac Oncol. 2012; 7: 1640-4.

87. Mok TS, Wu YL, Thongprasert S, Yang CH, Chu DT, Saijo N, Sunpaweravong P, Han B, Margono B, Ichinose Y, Nishiwaki Y, Ohe Y, Yang JJ, et al. Gefitinib or carboplatin-paclitaxel in pulmonary adenocarcinoma. N Engl J Med. 2009; 361: 947-57.

88. Mok T, Wu YL, Lee JS, Yu CJ, Sriuranpong V, SandovalTan J, Ladrera G, Thongprasert S, Srimuninnimit V, Liao M, Zhu Y, Zhou C, Fuerte F, et al. Detection and Dynamic Changes of EGFR Mutations from Circulating Tumor DNA as a Predictor of Survival Outcomes in NSCLC Patients Treated with First-line Intercalated Erlotinib and Chemotherapy. Clin Cancer Res. 2015; 21: 3196-203.

89. Wang Z, Chen R, Wang S, Zhong J, Wu M, Zhao J, Duan J, Zhuo M, An T, Wang Y, Bai H, Wang J. Quantification and dynamic monitoring of EGFR T790M in plasma cell-free DNA by digital PCR for prognosis of EGFR-TKI treatment in advanced NSCLC. PLoS One. 2014; 9: e110780.

90. Ishii H, Azuma K, Sakai K, Kawahara A, Yamada K, Tokito T, Okamoto I, Nishio K, Hoshino T. Digital PCR analysis of plasma cell-free DNA for non-invasive detection of drug resistance mechanisms in EGFR mutant NSCLC: Correlation with paired tumor samples. Oncotarget. 2015; 6: 30850-8. https://doi.org/10.18632/oncotarget.5068.

91. Zheng D, Ye X, Zhang MZ, Sun Y, Wang JY, Ni J, Zhang HP, Zhang L, Luo J, Zhang J, Tang L, Su B, Chen G, et al. Plasma EGFR T790M ctDNA status is associated with clinical outcome in advanced NSCLC patients with acquired EGFR-TKI resistance. Sci Rep. 2016; 6: 20913.

92. Isobe K, Hata Y, Tochigi N, Kaburaki K, Kobayashi H, Makino T, Otsuka H, Ishida F, Hirota N, Sano G, Sugino K, Sakamoto S, Takai Y, et al. Usefulness of nanofluidic digital PCR arrays to quantify T790M mutation in EGFR-mutant lung adenocarcinoma. Cancer Genomics Proteomics. 2015; 12: $31-7$.

93. Xu Q, Zhu Y, Bai Y, Wei X, Zheng X, Mao M, Zheng G. Detection of epidermal growth factor receptor mutation in lung cancer by droplet digital polymerase chain reaction. Onco Targets Ther. 2015; 8: 1533-41.

94. Masago K, Fujita S, Muraki M, Hata A, Okuda C, Otsuka K, Kaji R, Takeshita J, Kato R, Katakami N, Hirata Y. Nextgeneration sequencing of tyrosine kinase inhibitor-resistant non-small-cell lung cancers in patients harboring epidermal growth factor-activating mutations. BMC Cancer. 2015; 15: 908.

95. Paweletz CP, Sacher AG, Raymond CK, Alden RS, O’Connell A, Mach SL, Kuang Y, Gandhi L, Kirschmeier 
P, English JM, Lim LP, Janne PA, Oxnard GR. BiasCorrected Targeted Next-Generation Sequencing for Rapid, Multiplexed Detection of Actionable Alterations in CellFree DNA from Advanced Lung Cancer Patients. Clin Cancer Res. 2016; 22: 915-22.

96. Belchis DA, Tseng LH, Gniadek T, Haley L, Lokhandwala P, Illei P, Gocke CD, Forde P, Brahmer J, Askin FB, Eshleman JR, Lin MT. Heterogeneity of resistance mutations detectable by nextgeneration sequencing in TKItreated lung adenocarcinoma. Oncotarget. 2016; 7: 4523748. https://doi.org/10.18632/oncotarget.9931.

97. Su KY, Chen HY, Li KC, Kuo ML, Yang JC, Chan WK, Ho BC, Chang GC, Shih JY, Yu SL, Yang PC. Pretreatment epidermal growth factor receptor (EGFR) T790M mutation predicts shorter EGFR tyrosine kinase inhibitor response duration in patients with non-small-cell lung cancer. J Clin Oncol. 2012; 30: 433-40.

98. Karlovich C, Goldman JW, Sun JM, Mann E, Sequist LV, Konopa K, Wen W, Angenendt P, Horn L, Spigel D, Soria JC, Solomon B, Camidge DR, et al. Assessment of EGFR Mutation Status in Matched Plasma and Tumor Tissue of NSCLC Patients from a Phase I Study of Rociletinib (CO1686). Clin Cancer Res. 2016; 22: 2386-95.

99. Sorensen BS, Wu L, Wei W, Tsai J, Weber B, Nexo E, Meldgaard P. Monitoring of epidermal growth factor receptor tyrosine kinase inhibitor-sensitizing and resistance mutations in the plasma DNA of patients with advanced non-small cell lung cancer during treatment with erlotinib. Cancer. 2014; 120: 3896-901.

100. Marchetti A, Palma JF, Felicioni L, De Pas TM, Chiari R, Del GM, Filice G, Ludovini V, Brandes AA, Chella A, Malorgio F, Guglielmi F, De TM, et al. Early Prediction of Response to Tyrosine Kinase Inhibitors by Quantification of EGFR Mutations in Plasma of NSCLC Patients. J Thorac Oncol. 2015; 10: 1437-43.

101. Sequist LV, Rolfe L, Allen AR. Rociletinib in EGFRMutated Non-Small-Cell Lung Cancer. N Engl J Med. 2015; 373: 578-9.

102. Zhang X, Chang A. Somatic mutations of the epidermal growth factor receptor and non-small-cell lung cancer. J Med Genet. 2007; 44: 166-72.

103. Kobayashi S, Boggon TJ, Dayaram T, Janne PA, Kocher O, Meyerson M, Johnson BE, Eck MJ, Tenen DG, Halmos B. EGFR mutation and resistance of non-small-cell lung cancer to gefitinib. N Engl J Med. 2005; 352: 786-92.

104. Lee JY, Qing X, Xiumin W, Yali B, Chi S, Bak SH, Lee HY, Sun JM, Lee SH, Ahn JS, Cho EK, Kim DW, Kim HR, et al. Longitudinal monitoring of EGFR mutations in plasma predicts outcomes of NSCLC patients treated with EGFR TKIs: Korean Lung Cancer Consortium (KLCC-12-02). Oncotarget. 2016; 7: 6984-93. https://doi.org/10.18632/ oncotarget.6874.

105. Watanabe M, Kawaguchi T, Isa S, Ando M, Tamiya A, Kubo A, Saka H, Takeo S, Adachi H, Tagawa T, Kakegawa S, Yamashita M, Kataoka K, et al. Ultra-Sensitive Detection of the Pretreatment EGFR T790M Mutation in Non-Small Cell Lung Cancer Patients with an EGFR-Activating Mutation Using Droplet Digital PCR. Clin Cancer Res. 2015; 21: 3552-60.

106. Taniguchi K, Uchida J, Nishino K, Kumagai T, Okuyama T, Okami J, Higashiyama M, Kodama K, Imamura F, Kato K. Quantitative detection of EGFR mutations in circulating tumor DNA derived from lung adenocarcinomas. Clin Cancer Res. 2011; 17: 7808-15.

107. Hashida S, Soh J, Toyooka S, Tanaka T, Furukawa M, Shien K, Yamamoto H, Asano H, Tsukuda K, Hagiwara K, Miyoshi S. Presence of the minor EGFR T790M mutation is associated with drug-sensitive EGFR mutations in lung adenocarcinoma patients. Oncol Rep. 2014; 32: 145-52.

108. Hagemann IS, Devarakonda S, Lockwood CM, Spencer DH, Guebert K, Bredemeyer AJ, Al-Kateb H, Nguyen TT, Duncavage EJ, Cottrell CE, Kulkarni S, Nagarajan $\mathrm{R}$, Seibert K, et al. Clinical next-generation sequencing in patients with non-small cell lung cancer. Cancer. 2015; 121: 631-9.

109. Maheswaran S, Sequist LV, Nagrath S, Ulkus L, Brannigan $\mathrm{B}$, Collura CV, Inserra E, Diederichs S, Iafrate AJ, Bell DW, Digumarthy S, Muzikansky A, Irimia D, et al. Detection of mutations in EGFR in circulating lung-cancer cells. N Engl J Med. 2008; 359: 366-77.

110. Costa C, Molina MA, Drozdowskyj A, Gimenez-Capitan A, Bertran-Alamillo J, Karachaliou N, Gervais R, Massuti B, Wei J, Moran T, Majem M, Felip E, Carcereny E, et al. The impact of EGFR T790M mutations and BIM mRNA expression on outcome in patients with EGFRmutant NSCLC treated with erlotinib or chemotherapy in the randomized phase III EURTAC trial. Clin Cancer Res. 2014; 20: 2001-10.

111. Yu HA, Arcila ME, Rekhtman N, Sima CS, Zakowski MF, Pao W, Kris MG, Miller VA, Ladanyi M, Riely GJ. Analysis of tumor specimens at the time of acquired resistance to EGFR-TKI therapy in 155 patients with EGFR-mutant lung cancers. Clin Cancer Res. 2013; 19: 2240-7.

112. Sueoka-Aragane N, Katakami N, Satouchi M, Yokota S, Aoe K, Iwanaga K, Otsuka K, Morita S, Kimura S, Negoro S. Monitoring EGFR T790M with plasma DNA from lung cancer patients in a prospective observational study. Cancer Sci. 2016; 107: 162-7.

113. Zhao J, Xie F, Zhong W, Wu W, Qu S, Gao S, Liu L, Zhao J, Wang M, Zhou J, Jie H, Chen W. Restriction endonuclease-mediated real-time digestion-PCR for somatic mutation detection. Int J Cancer. 2013; 132: 2858-66.

114. Jin Y, Shao Y, Shi X, Lou G, Zhang Y, Wu X, Tong X, $\mathrm{Yu}$ X. Mutational profiling of non-small-cell lung cancer patients resistant to first-generation EGFR tyrosine kinase inhibitors using next generation sequencing. Oncotarget. 2016; 7: 61755-61763. https://doi.org/10.18632/ oncotarget.11237.

115. Oxnard GR, Thress KS, Alden RS, Lawrance R, Paweletz 
CP, Cantarini M, Yang JC, Barrett JC, Janne PA. Association Between Plasma Genotyping and Outcomes of Treatment With Osimertinib (AZD9291) in Advanced NonSmall-Cell Lung Cancer. J Clin Oncol. 2016; 34: 3375-82.

116. Takahama T, Sakai K, Takeda M, Azuma K, Hida T, Hirabayashi M, Oguri T, Tanaka H, Ebi N, Sawa T, Bessho A, Tachihara M, Akamatsu H, et al. Detection of the T790M mutation of EGFR in plasma of advanced nonsmall cell lung cancer patients with acquired resistance to tyrosine kinase inhibitors (West Japan oncology group 8014LTR study). Oncotarget. 2016; 7:58492-58499. https:// doi.org/10.18632/oncotarget.11303.

117. Seki Y, Fujiwara Y, Kohno T, Takai E, Sunami K, Goto Y, Horinouchi H, Kanda S, Nokihara H, Watanabe S, Ichikawa H, Yamamoto N, Kuwano K, et al. PicoliterDroplet Digital Polymerase Chain Reaction-Based Analysis of Cell-Free Plasma DNA to Assess EGFR Mutations in Lung Adenocarcinoma That Confer Resistance to TyrosineKinase Inhibitors. Oncologist. 2016; 21: 156-64.

118. Han JY, Lee KH, Kim SW, Min YJ, Cho E, Lee Y, Lee SH, Kim HY, Lee GK, Nam BH, Han H, Jung J, Lee JS. A Phase II Study of Poziotinib in Patients with Epidermal Growth Factor Receptor (EGFR)-Mutant Lung Adenocarcinoma who Have Acquired Resistance to EGFR-Tyrosine Kinase Inhibitors. Cancer Res Treat. 2017; 49: 10-19.

119. Chai X, Ren P, Wei B, Ma J, Mai L, Cram DS, Song Y, Guo Y. A comparative study of EGFR oncogenic mutations in matching tissue and plasma samples from patients with advanced non-small cell lung carcinoma. Clin Chim Acta. 2016; 457: 106-11.

120. Sakai K, Horiike A, Irwin DL, Kudo K, Fujita Y, Tanimoto
A, Sakatani T, Saito R, Kaburaki K, Yanagitani N, Ohyanagi F, Nishio M, Nishio K. Detection of epidermal growth factor receptor T790M mutation in plasma DNA from patients refractory to epidermal growth factor receptor tyrosine kinase inhibitor. Cancer Sci. 2013; 104: 1198-204.

121. Uchida J, Imamura F, Kukita Y, Oba S, Kumagai T, Nishino K, Inoue T, Kimura M, Kato K. Dynamics of circulating tumor DNA represented by the activating and resistant mutations in epidermal growth factor receptor tyrosine kinase inhibitor treatment. Cancer Sci. 2016; 107: 353-8.

122. Rosell R, Molina MA, Costa C, Simonetti S, GimenezCapitan A, Bertran-Alamillo J, Mayo C, Moran T, Mendez $\mathrm{P}$, Cardenal F, Isla D, Provencio M, Cobo $\mathrm{M}$, et al. Pretreatment EGFR T790M mutation and BRCA1 mRNA expression in erlotinib-treated advanced non-small-cell lung cancer patients with EGFR mutations. Clin Cancer Res. 2011; 17: 1160-8.

123. Molina-Vila MA, Bertran-Alamillo J, Reguart N, Taron M, Castella E, Llatjos M, Costa C, Mayo C, Pradas A, Queralt C, Botia M, Perez-Cano M, Carrasco E, et al. A sensitive method for detecting EGFR mutations in non-small cell lung cancer samples with few tumor cells. J Thorac Oncol. 2008; 3: 1224-35.

124. Yu JY, Yu SF, Wang SH, Ba H, Zhao J, An TT, Dua JC, Wan J. Clinical outcomes of EGFR-TKI treatment and genetic heterogeneity in lung adenocarcinoma patients with EGFR mutations on exons 19 and 21. Chin J Cancer. 2016; $35: 4$. 